University of Rhode Island

DigitalCommons@URI

Open Access Master's Theses

1984

\title{
A LEGISLATIVE APPROACH TO REGULATING SOLAR ACCESS: AMENDMENTS TO THE PROPOSED RHODE ISLAND ZONING ENABLING ACT OF 1984
}

Amy Abramson-Denhoff

University of Rhode Island

Follow this and additional works at: https://digitalcommons.uri.edu/theses

\section{Recommended Citation}

Abramson-Denhoff, Amy, "A LEGISLATIVE APPROACH TO REGULATING SOLAR ACCESS: AMENDMENTS TO THE PROPOSED RHODE ISLAND ZONING ENABLING ACT OF 1984" (1984). Open Access Master's Theses. Paper 552.

https://digitalcommons.uri.edu/theses/552

This Thesis is brought to you for free and open access by DigitalCommons@URI. It has been accepted for inclusion in Open Access Master's Theses by an authorized administrator of DigitalCommons@URI. For more information, please contact digitalcommons-group@uri.edu. 
MASTER OF COMMUNITY PLANNING

RESEARCH PROJECT

OF

AMY ABRAMSON-DENHOFF

Approved:

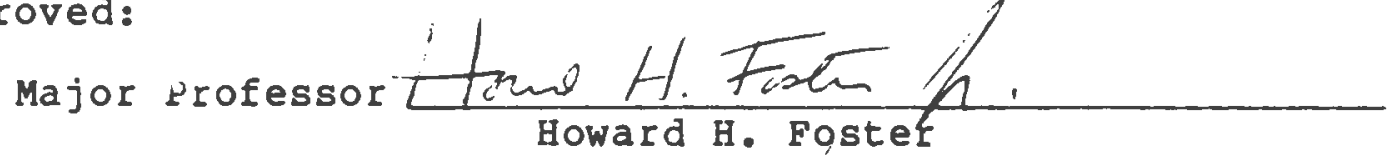

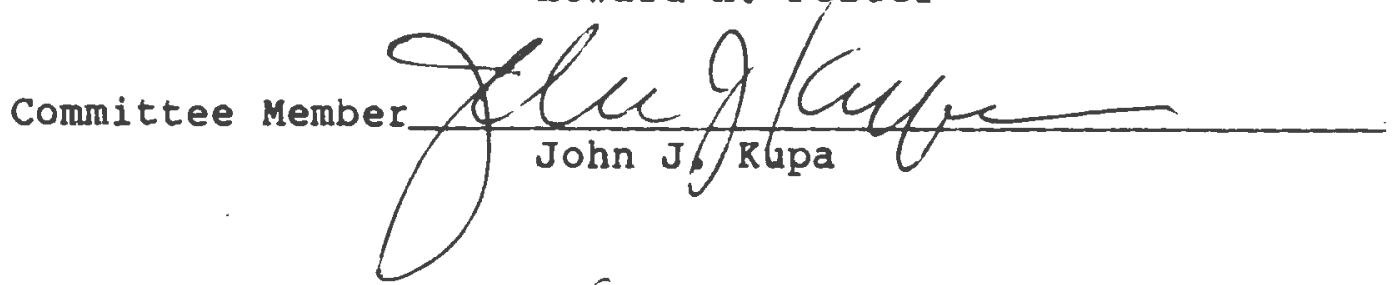

Acknowledged:

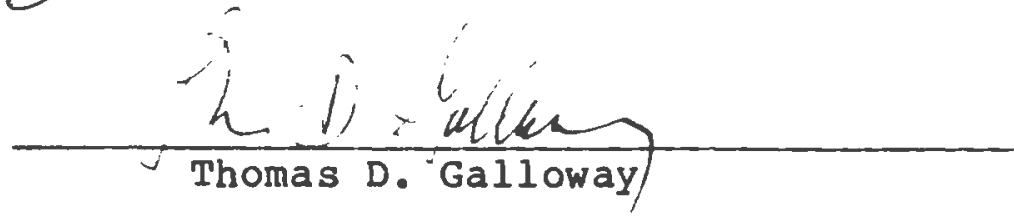




\begin{abstract}
A LEGISLATIVE APPROACH TO
REGULATING SOLAR ACCESS:

AMENDMENTS TO $\neg \mathrm{HE}$ PROPOSED

RHODE ISLAND ZUNING ENABLING

ACT OF 1984
\end{abstract}

BY

AMY ABRAMSON-DENHOFF

A RESEARCH PROJECT SUBMITTED IN

PARTIAL FULFILLMENT OF THE REQUIREMENTS

FOR THE DEGREE AND MASTER OF

COMMUNITY PLANNING

UNIVERSITY OF RHODE ISLAND

1984 
ACKNOWLEDGEMENTS

My special appreciation is extended to my parents: Harry and Libby, for their unselfish love, encouragement and support. Their nurturing has enabled me to blossom and grow. To Lisa and Cookie, I thank them for their humor and understanding throughout the past 28 years. To my husband Joe, I thank him for teaching me the feasibility of researching and writing this project while basking in the sun on the shores of Duck Cove. I also extend my deep appreciation to Dr. Howard Foster; Dr. Thomas Galloway; Dr. John Kupa and Mr. Rick Keller for providing me with their insight and knowledge during this learning process. 


\section{TABLE OF CONTENTS}

Page

Chapter 1 Baics of Solar Energy for the Land Use Planner I

Chapter 2 Legal Aspects of Solar Access 11

Chapter 3 Amendments to the Propnsed Rhode Island $z$ oning Enabling $A$ t of 1984

Appendix I Rhode Island Zoning E-abling Act of 1984

Appendix II Revisions to the Zonl 3 Ordinance for F ster, Rhode Island

Appendix III Town Energy Resoluticn

Appendix IV Comprehensive Energy "anagement Plan for Foster, Rhode Island 


\section{FIGURES}

Page

Figure 1 A Typical Active Solar Energy System 3

Figure 2 A Typical Passive Heating System 4

Figure $3 \quad$ Lattitudes of the Contiguous States 7

Figure 4 Radiation and Shadow Length on a 8 South slope 
CHA TER 1

BASICS OF SOLAR ENERGY

FOR ${ }^{\mathrm{m} H E}$

LAND USE PLANNER 
The use of solar energy as a viable means of heating and cooling buildings has greatly increased within the past ten years. In 1974, Congress stated in the solar Energy Researche Development and Demonstrat: n: that ". . it is in the Nation's best inte est to expedite the long-term development of renewable and non-polluting energy resources, such as solar energy. - ${ }^{1}$ The realization that fossil fuels are becoming increasingly scarce, coupled with the political ramifications of our dependence upon such fuels has led to greater public acceptance and Congressional recognition of the importance in seeking alternative energy sources. Both technological advancement and increased economic feasibility, have also led to the growth and development of solar technology. This growth will continue if tr use th this solar technology is assured access to the sun. There are certain land use tools which the planner can utilize to insure that access to sunlight is assured for the current and future solar energy user.

In order that the land use planner facilitate the full use of solar energy, he must understand at least two basic principles which are relevant to solar energy. The following discussion centers on these two principles: solar energy systems and solar access.

A solar energy system is a device used to capture the sun's radiation and transform it into usable heat. Solar energy systems usually consist of four separate components: a solar 
collector; a transfer system; a storage system; and a control system. For solar access purposes, the planner need only be concerned with the collector because it is here that solar radiation enters the system. 3

Solar energy systems are divided into two categories: active and passive. In an active system, heat generated by the solar collector is movet by fans and pumps from the collector to storage or to the place where usable he-t is needed ${ }^{4}$ (see figure 1) The most well-known type of collactor is the nflat-plate collector", which t. a glass covered insulated box containing an absorber plate. These collectors are ssually located either on a building utilizing solar energy or an aujacent building such as a garage or storage shed. In New England, it would be more advantegous to install an active system, because of the potential to store the energy for use at another time, when it may be cloudy, raining or snowing.

A passive system is often referred to as a direct system because the heat is used at the place where it is generated. (see figure 2) In the usual passive system, solar energy is "collected" through south-facing glass. absorbed in the mass of the building (or in special storage elements), and distributed to adjacent areas by radiation and convection. A building that is heated through passive solar energy often appears to be similar to a home that is heated by oil, wood, or coal. This is because the passive system usually operates without any moving parts.

Solar access refers to the availability of sunlight to solar energy systems. Protecting this access implies preventing shadows from vegetation, buildings or other obstructions from 
Figure 1. A "ypical A.tive jolar Hnorry jystem

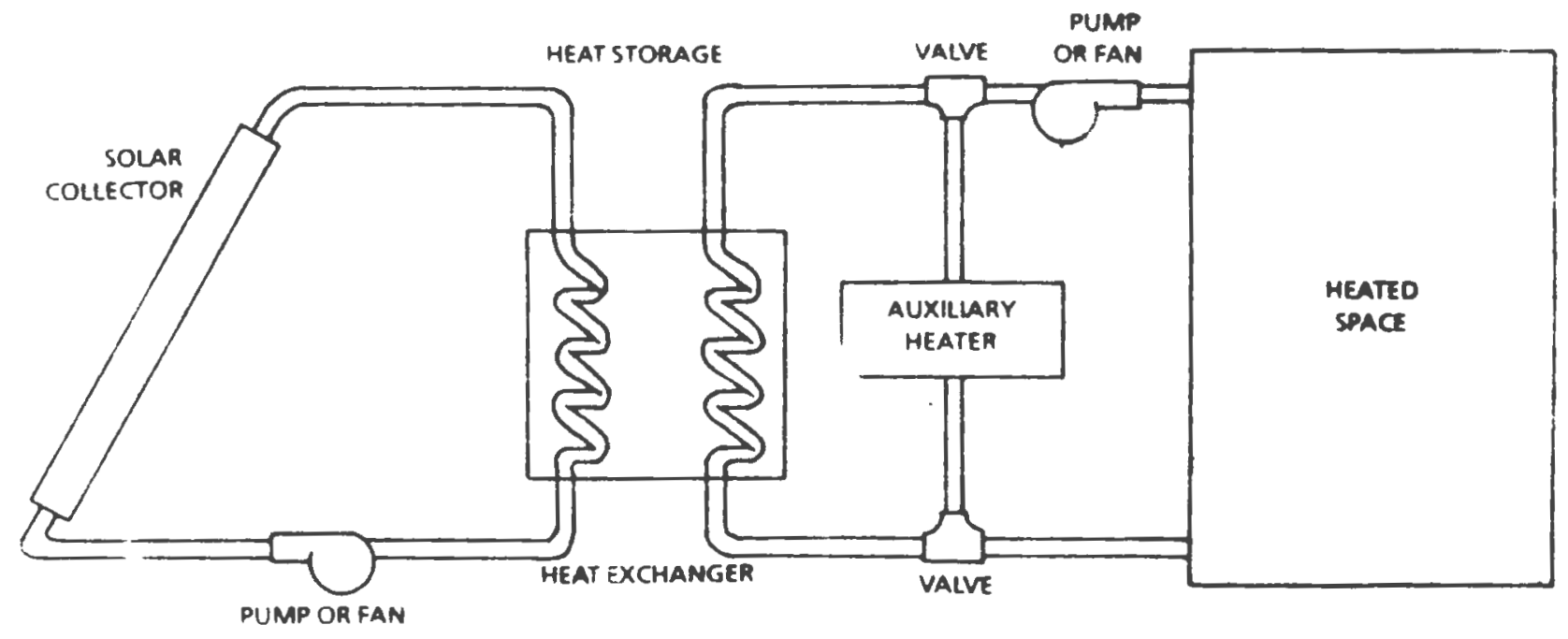

\footnotetext{
oure: 4.U. . publication: "Protecting nlar Access

for Residential levelopment: A iu der rok or Planning rfficials."
} 
Himure 2. A Typical Passive Heating Sys'em
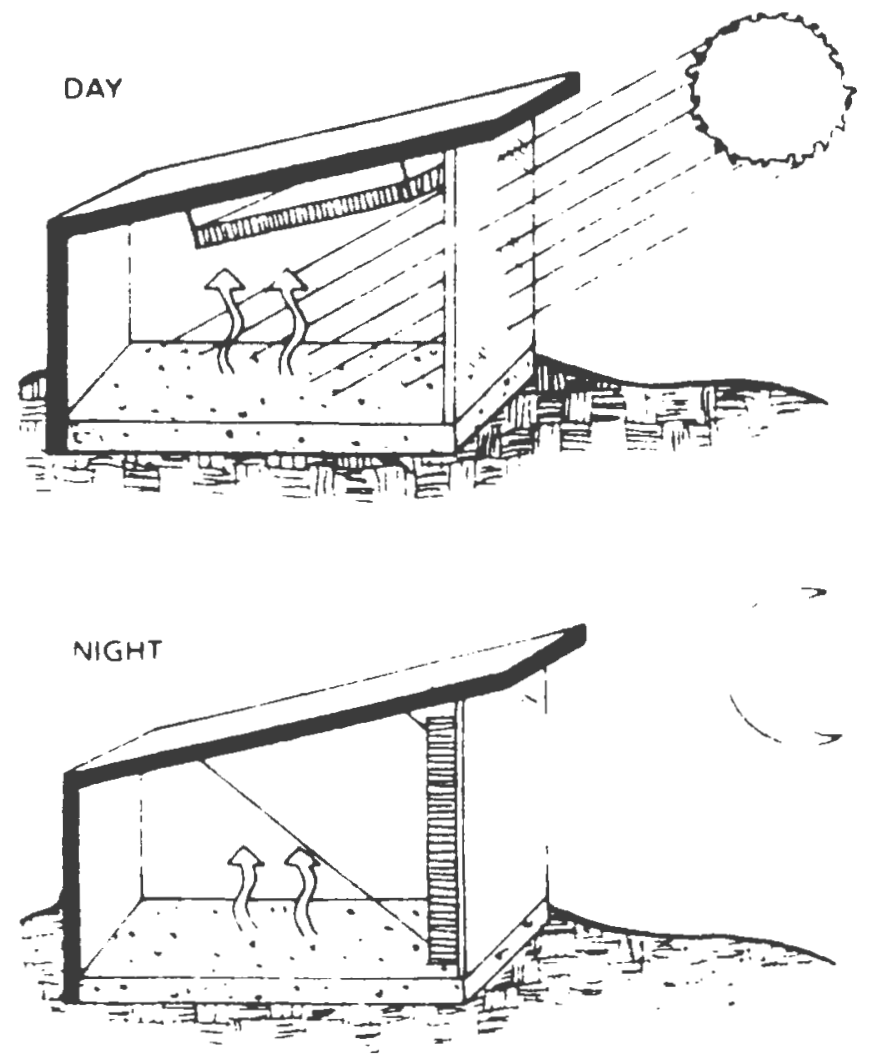

A passive space heating system south-facing id is the collector, a concrete floor siab acts as storage, the heat radiates naturally

Source: H.U.D. Publication: "Protectine. Eolar Access for Residential Development: A iuidebook for Planning Officials." 
shading the solar system. Several factors influence the amount of sunlight that falls onto a particular site. These factors also influence the ease or difficulty of protecting access to that sunlight. Some of these factors include l) the suns relationship with the earth; which influences 2) the latitude of the site of the structure; and 3) the topography of the site.

The first factor of solar access involves the relationship between the earth and the sun. The earth revolves around the sun and rota' $s$ on its axis once a day. Th. gives the impression of sun travei. Unfortunately for solar access, only at the equator does the sun travel directly overhead; everywhere else it moves at an angle to the earth's surface. In the northeastern United States, the sun is lower than it is in southern states, thereby creating longer shadows. As the year progresses from winter to summer, the maximum altitude of the sun increases daily until it reaches its highest point on the summer solstice (usually June 21). After June 21, the altitude begins to drop until it reaches its lowest point on December 21, the winter solstice, the day with the longest shadows. The suns relationship with the earth provides us with a cyclical problem: in the Northeastern U.S., one would be more abt to want to utilize a solar energy system to heat his home because the winters are cold and long. Yet in the Northeastern U.S., the shadows created from buildings, and vegetation are longer, creating greater difficulty in assuring solar access for the solar energy system. The problem is that the reason the winters are cold and long is berause of the latitude of Northeastern U.S. region.

Another factor relevant to solar access involves the 
latitude of the site. Latitude is a measure of the angle between the equatorial plane and the zenith of point south on the earth's surface. As can be deduced from Figure 3, the equator is at zero degrees and both the South and North poles are at 90 degrees.

Here it is important that the planner understand the implications of latitude for protecting solar energy systems. The suns angles vary with latitude because the sun strikes different global points at varyirs angles. As one travels north in the United states, the angle of the sun is lower, due to the curved surface of the earth near the poles. The highor the earth's latitude, the lower the sun is in the sky, creat ..g longer shadows. These longer shadows make it difficult to protect solar collectors from snade, making solar energy systems less effective. For example, as Figure 3 illustrates, Providence, RI would be at approximately 42 degrees, and Jacksonville, Florida would be at approximately 30 degrees. Therefore, protecting solar energy systems from = hade at a site in providence would be more difficult because it is farther north than Jacksonville and the angle of the sun is lower, creating longer shadows.

The final solar access factor to be discussed is the topography of a given site. The potential for solar access is often influenced by the slope of the given site. As the degree of slope changes, the angle at which the sun strikes the site also changes. As figure 4 illustrates, more concentration of solar radiation is gained on a south facing slope than on south facing flat land. This figure also illustrates that the shadows are shorter on sloped land than on the flat land. These shorter shadows increase the amount of available sunlight, thereby 
Fipure $\%$ Intitutes of the Contipuous States

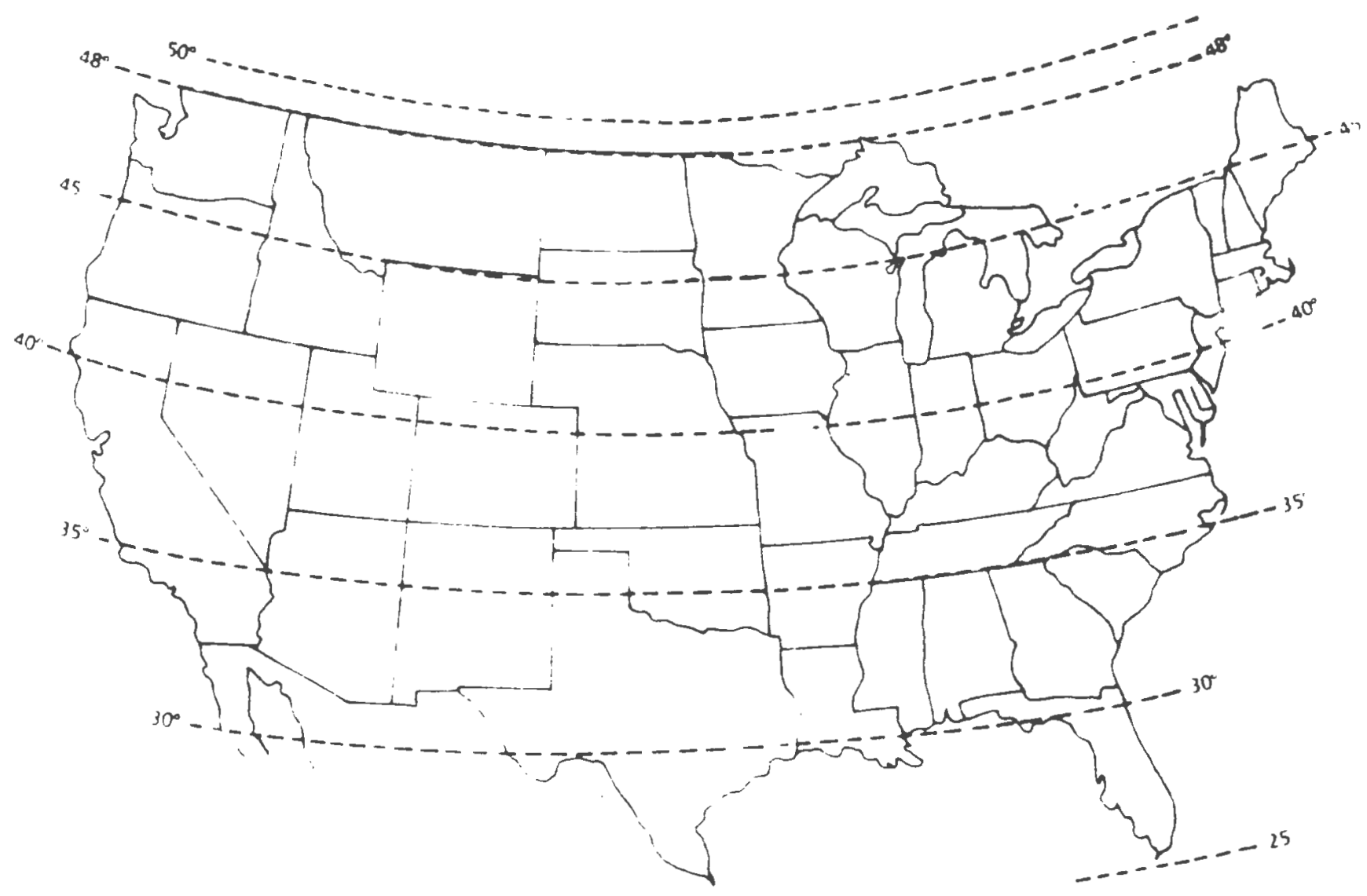

Source: H.U.D. Publication: "Protecting Jolar Access for Residential Development: A Culdebook for Planning Cricials." 
Fipure 4. Rar" ation and Shadow Length on a jouth.jlope

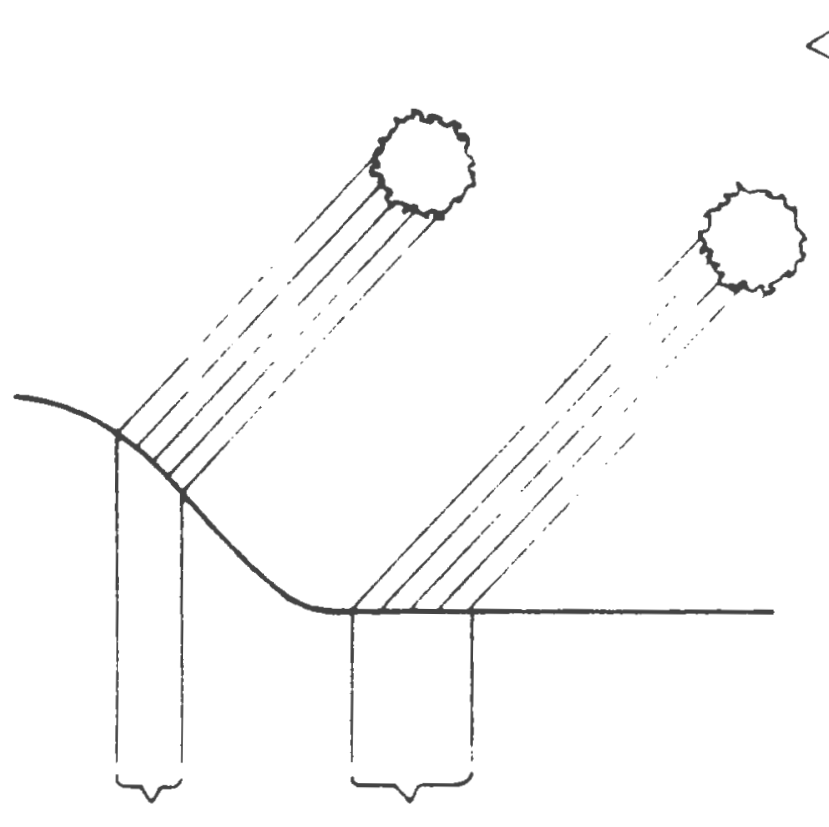

A

8

Area of ground receiving the ray on flat ground, (B) is larger than arsa on south slope, (A) Thus more energy is received per unit area on the slope

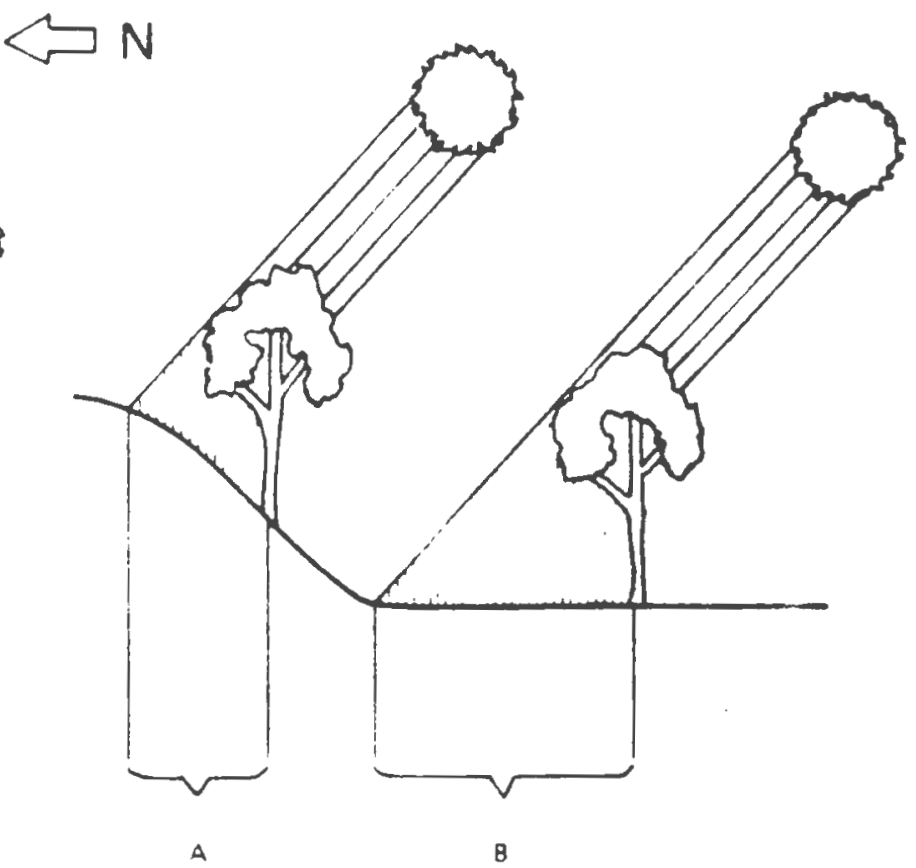

Shadr' $N$ rast by tree on flat ground, (B), is longer than e one cast by same tree on south slope. (A)

\footnotetext{
jource: H.U.Z. publication: "Frotecting jolar Access for Residential Development: A Cuidebonk for Planning Cfficials.
} 
increasing solar gain. While it is not the ideal situation, it is possible to place a solar collector on a building with a north facing slope, and position the solar collertor to the south.

The above discussion has given the planner an overview of th: basics of solar energy. Protecting solar access to the solar energy systems depends on many factors including the relation: ip between the earth and the sun; latitude and topography. It is important that the planner understand these factors if he is to utilize the land use tools available to bim to plan and regulate for solar access.

It is also important for the planner to understand the legal framework for regulating solar access. The next chapter will present a review of the evolution of legal thinking on the regulation of solar access, as well as the current legal framework with which the planner will be working. 
CHAPTER 2

LEGAL AS ECME

OF

SOLAR ACCESS 
As Chapter 1 illustrated, use of solar energy is dependent upon access to direct sunlignt in order to utilize the active or passive collector mechanism. Receiving access to direct sunlight involves a variety oL legal issues because as the sun's rays strike the earch, they strike at an angle of iess than 90 degrees to our planet and therefore have the potential to bisect another piece of land. s a consequence, a person'. solar acce-s may be blocked by his neighbor's structures, vegetation, or land formation. Here a potential conflict may be created. The question arises, that as a matter of right, can the user sf solar energy demand access to direct sunlight?

Several categories of law, wi,..in English common law, help define solar access. The Engli Common Law Doctrine of Ancient Lights is the oldest legislative doctrine tnat is applicable to solar access. The Doctrine of Ancient Lights provides that if a landowner has received light from across his neighbor's land for a certain period of time, he has a right to continue enjoying it.

In the past, most American courts have repeatedly refused to recognize a "right to light". The most prevalent case in thi area is the 1958 Miami, Florida case of Eountainbleau Hotel Corp. L. Forty-Five Twenty-Five, Inc. The arguments presented by the Eden Roc Hotel, owned by Forty-Five Twenty-Five, Inc. were based on the theories of the Doctrine of Ancient Lights: the Eden Roc assumed that they were entitled to the see flow of sunlight and air onto its property. 
In this case, the Eden Roc Hotel, located not th of the Fountainbleau Jotel included an outdoor swimming pool on the $r$ southern property line. A few months after the notel was built, the Fountainbleau began to build a fourtsen stoly high addition which in effect would place the Eden Roc swimming pool in shadow. Eden Roc filed suit, seeking temporary injunction on construction. Eden Roc al'edged that the Fountainbleau was acting with malice and interfering with implied "easements of light and air" enjoyed for more than twenty years by the Eden Roc and its predecessors." ${ }^{3}$ The trial court granted the temporary injunction. The court stated that one property owner is not entitled to use his property at the expense of injuring a neighboring property owner.

The Fountainbleau Hotel appealed the case and Lne decision of the trial court was reversed. The Florida Court of Appeals stated that one property owner must not use his property to injure the "lawful rights" of another property owner. The court pointed out that in this country these is no lawful right to free access of light or air. Because the free flow of light or air is not a protected lawful right, Eden Roc had no valid claim against Fountainbleau. As a result Eden Roc had to absorb the loss of not being able to fully enjoy the use of their swimming pool, and therefore, they built a new pool on a different parcel of land. Essentially, the courts stated that one property owner is not entitled to own certain rays of the sun that strike in a specific geographical area. 
Both the Doctrine of Ancient Lights and the Fountainbleau Hotel Corp. v. Forty-Five Twenty-Five, Inc. case are based on the theory of prescriptive easement. This prescriptire easement is a right to use the land of another acquired by long continued use of the land in the past which prevents the owner of the servient (used) land from making another use of his land which would interfere with the easement. For solar access purposes, enforcement of an easement means that the end user is allowed to prohibit an adjacent property owner from blocking access to the the sunlight needed to operate his collector.

Even if the courts did accept a "right to light", the Doctrine is unworkable becuase of two major limitations: amount of time and amount of light.

First, to insure solar access, the length of time necessary for a landowner to validly claim that he has received light from the adjacent land is twenty-seven years. Considering the rampant development of land in America today, this prescription appears unrealistic. Scholars often ask if the 27 year requirement is shortened, what constitutes a reasonable amount of time for a landowner to enjoy or receive light from adjacent land?

The second limitation of the Doctrine of Ancient Lights is the amount of allowable light. The Doctrine states that the amount of light required for solar access should be sufficient to read a book in the center of a room. This is not a useful standard as it would be difficult to relate the light needed to read a book to the amount of light needed for a solar collector. Modification of the doctrine to establish contemporary solar access rights may be somewhat difficult. This is because 
societys' preferences and priorities during the era of the Common Law Doctrine are different fr $\mathrm{n}$ those of tcday. The Ancient Lights Doctrine is a protection of the individual; insuring his right to sunlight within his home. A solar access policy would have to insure that enr.gh sunlight strikes the collector to maximize the sun's rays. Such a policy would have to apply to both residential and industrial properties, the later requiring more entrgy than the former. Th sefore it would be very difficult to define legally the concept of enough sunlight as well as maximizing the sun's rays.

It is clearly evident tha there are di-ficulties in relating the Doctrine of Ancient Lights/prescriptive easements to the solar access issue. Other common-law approaches have been offered to the courts as a means of solving the solar access problem, one of which is the common law of nuisance.

"To meet the burden of proof, the plaintiff in a nuisance suit must show irreparable damage and demonstrate that the hardship would be greater than would be caused by enjoining the defendant's activity-e standard the solar-energy user probably could not satisfy." 6

Solar easements are another approach, yet they are limited in use. In 1975, Colorado was the first to enact a statute providing procedural guidelines for express solar easements. Colorado's statute explains procedures for recording easements for light and air that are voluntarily set between neighboring property owners. "As minimal pre-requisites, the recording must contain the vertical and horizontal easement angle, the terms for termination, and the amount of compensation given in return for the granting of the easement. " ${ }^{7}$ One inherent problem with the 
express easement is in the weighing of costs and benefits. In a densely populated city such as Manahattan, the cost of purchasing an easement may far outweigh the personal benefits of utilizing the sun's rays for heating and cocling a building.

in this instance though, the benefits to society in conserving fossil-fuels are prevalent. The user of a solar collector is expending his own money to acrue these societ + benefits. For such cases, a solar energy tax incentive may provide the answer.

Another problem with this tyce of easement is that it rewards the "wrong" individual. It allows the owner of a parcel of land or building to sell an easement so an energy conscious property owner. The individual tilizing the solar energy is not being rewarded, but must pay for the guarantee of solar access. Restrictive covenants have also been offered as a solution. However, covenants have severe limitations since they offer little help to established neighborhoods or cities with commercial and industrial land.

Realizing that many common-law approaches have not solved the problem of protecting solar access, many states have enacted enabling legislation dealing with the issue of solar access.

Zoning is one of these legislative approaches that is gaining acceptance, as many states realize that it is a viable means of guaranteeing solar access. It is a desirable and legally appropriate tool for creating solar rights and may be easier to administer than the above mentioned approaches. Solar rights must be created in such a way that they are acceptable to society; otherwise, they will nut have any practical effect. Acceptability lies in minimizing any inconvenience to a solar 
owner's neigabor while, at the same time, guaranteeing the solar user sufficient solar energy. A properly conceived zoning ordinance can reach an acceptable trade-off betweer the $e$ dual interests." ${ }^{8}$ The Rhode Island 1984 zoning Enabling Legislation clues into these interests in many sections. One of these is in section 45-24-26 Legislative Findings \& Intent:

(a) The general assembly finds that the land of Rhode island is a finite natural resource that must be carefully managed in order to:

(5) meet needs for energy, water and waste disposal

(10) protect valuable natural resources

Under the general purposes of the ord ance, section 45-24-28, the zoning ordinance may:

(c) promote the conservation of energy, open space, natural resources, and significant natural features

(k) provide adequate $1+y_{.} \pm$and air

Also, under section 45-24-28b, a zoning ordinance may include provisions for:

(3) Regulating the height, number of stories, and size of buildings; and structures and the dimensions, size, building coverage, and layout of lots or development areas and regulating access to sinlight for solar energy systems.

Through the creation of solar rights, America would be reducing its dependence upon foreign countries and could also be reducing its consumption of a depleting resource. In a sense, this reduction would constitute a protection of the public health, safety and welfare of Americans, which in effect, is the general zurpose of zoning. Zoning ordirances regulate the height and bulk of buildings and the subdivisi n ordinances regulate the 
street layout and lot line orientation. While these regulations exist for promoting the oublic healt', s: sety, and welfare, they often impede the utilization and promotion of the suns rays for heating and cooling a building.

Therefore the conflict exists: the land use measures stated in most zoning ordinances do not effectively and fully promote and protect the public health, safety and welfare because they impede utilization of the sun's rays for solar energy purposes. The next chapter will illustrate how this conflict can be alleviated. The chapter will contain revisions to the Rhode Island Zoning Enabling Act of 1984. These revisions will illustrate how the land use regulations stated in the Act can complement a solar conscious community. 
1 William H. Lawrence and John H. Minan, Legal Aspects of Solar EnErgy (Lexington: Lexington Loks, 1981), p. 27.

2

Fountainbleau Hotel Corp. v. Forty-Five Twenty Five, Inc., 114 So.2d 357, 359 (District Court of Appeals, Fla. 1959).

3

Minan; Lawrence, Legal Aspects of Solar Energy p.27.

4

Ibid., p. 53 .

5

Ibid., p. 46.

6

Minan; Lawrence, Legal Aspects of Solar Energy, p. 45

7

"Legislative approact to Solar Access: Transferable Development Rights," New England Law Reviewe (Spring 1978): 13 p. 864.

8

Minan; Lawrence, Legal Aspects of Solar Energy, p. 45.

9

Ibid., p. 46 
CFAPTER 3

\section{AMENDMENTS TO THE \\ PROPCSED RHODE ISLAND \\ ZONING ENABLING ACT \\ OF 1984}


Most state zoning enabling acts are variations on the Standard State zoning Enabling Act, (called the Standard Act) promulgated by the United States Department of Commerce. While some state enabling acts may not be exactly the same as the Standard Act, most reflect the thinking behind the Act.

The Rhode Island zoning Enabling Act currently in use was enacted in 1956. In 1984, a new Act was introduced into the RI Legislation, yet was not passed. This proposed 1984 Act contained wording that vaguely hinted at prctection of solar access. Although this 1984 ict is not the official Rhode Island Zoning Enabling Act, it was amended by this author because it contained more emphasis on solar energy than did the 1956 Act. Additions to the proposed Act are noted by underlining, while deleted text is "struck out." Both the additions and deletions are discussed at the end of the chapter. 
It is enacted by the General Assembly as follows:

SECTION 1. Chapter 45-24 of the Rhode Island General Laws of 1956, as amended, entitled "Zoning Ordinances" is hereby amended as follows:

45-24-24.- Sections 24 through 53 of Title 45 Chapter 24 of the Rhode Island General Laws shall be known as the "Rhode Island Zoning Enabling Act of $1984^{\prime \prime}$.

45-24-25. Continuation of Ordinances-Supercession-Relation to other statutes

[Nr Change]

45- 4 4-26. Legislative Findings \& Intent

(a) The gene:al assembly finds that the land of Rhode Island is a finite natural resource that mist be carefully managed in order to: (1) accommodate needs for land; recognize the varying capability of land to support development; (3) prevent haphazard scattering of urban growth throughout rural areas, which results in increased servi e costs and loss of open space: (4) locate development with consideration of the required level and cost of public services; (5) meet needs for energy, water, and waste disposal; (6) forestall preemption of the few sites that are suitable for certain essential facilities by uses with less demanding requirements; (7) mitigate problems in finding acceptable locations for essential facilities with important social, economic or environmental impacts; (8) ensure housing choice; (9) discourage conversion of productive 
agricultural land and forests to other uses; (10) protect valuable natural resources; (Ii) avoid construction in hazardous locations; (12) avert amage to historic, archaeological, and architectural landmarks; (13) give attention to design and visual quality; and $114 ;$ :ec -e expenditure of effort by communities competing for land uses that pay high property taxes and make few demands on public services; and (15) provide protection of solar acciss to solar energy systems.

(b) [No Change]

(c) [No Change]

(d) [No Change]

45-24-27 Definitions.- As used in this act and in any zoning ordinance or amendment adopted in accordance with this act, the following words shall have the meanings stated herein.

(a) "Active Solar Energy System". A solar energy system that requires external mechanical power to move the collected heat.

(b) (-a-) "Agricultural Land". Land suitable for agricultural by reason of suitability of soil or other natural characteristics or past use for agricultural purposes. Agricultural land includes that defined as prime farm land or additional farm land of statewide importance for Rhode Island by the soil conservation service of the U.S. Department of Agriculture.

(c) (-b-) "Coastal Ponds and Shoreline Features". Water areas within the boundaries of the territorial sea of the state 
of Rhode Island that are directly affected by diurnal tides and associated brackish or freshwater bodies, and landforms contiguous to tidal waters and coastal ponds including coastal beaches and dunes, barrier beaches, coastal wetlands, coastal cliffs and banks, rocky shores, and manmade shorelines.

(d) (-e-) "Comprehensive Plan". A Comprehensive plan which has been adopted by the city or town planning board or commission and/or the city or town council pursuant to Chapter 45-22 of the General Laws of Rhode Island or to a home rule or legislative charter.

(e) (-d-) "Special Exception". A conditional use permitted in a particular zoning district only upon showing that such use in $\&$ specified location will comply with all the conditions and standards for the location or operation of such use as specified in a city or town zoning ordinance and authorized by the zoning board of review.

(f) (-e-) "Excessively Permeable Soils". Soils which have characteristics which, due to a relative fast movement of water in the soil, may cause pollution of groundwater. These include but are not limited to land mapped by the soil conservation service, J.S. Department of Agriculture, as the following soil series: Agawam, Bridgehampton, Deerfield, Enfield, GloucesterBridgehampton, Gloucester-Hinckley, Hinckley, Hinckley-Enfield, Lippitt, Merrimac, Ninigret, Quonset, Raypol, Scarboro, Sudbury, Tisbury, and windsor.

(g) (-f-) "Family". (1) One or more persons occuping a single housekeeping unit who are related by blood, marriage, or adoption, or where there is a legal responsibility for custody or 
care, and any domestic servants thereof, (2) not more than three adult persons who are not so related occuping a single housekeeping unit, or (3) a community residence licensed by the state for six or fewer retarded children or adults or not more than eight mentally disabled persons.

(h) (-g-) "Floodplains" cr "Flood Hazard Area". An area that has a one (1) percent is greater chance of inundaticn in any given year, as delineate ' by appropriate federal or state agencies, or by the city or town, using accepted hydrologic and engineering practices.

(i) (-h-) "Imperfectly Drained Soils". Land for which the estimated seasonal high water table level is less than four (4) feet from the ground surface, including but not limited to the following moderately-well drained, poorly drained, and very pe ly drained soil series mapped by the soil conservation service, U.S. Department of Agriculture: Adrian, Birchwood, Carlisle, Deerfield, Ipswich, Leicester, Mansfield, Matunuck, Ninigret, Pittstown, Podunk, Rainbow, Raypol, Ridgebury, Rumney, Scarboro, Scio, stissing, Sudbury, sutton, Tisbury, Walpole, Wapping, Whitman, and Wocdbridge.

(j) (-i-) "Land Development Project". A project in which one or more lots, tracts or parcels of land are to be developed as a coordinated site for a complex of activities, units or structures, including, but not limited to, residential cluster development, and planned development, when permitted by a city or town zoning ordinance and authorized by the planning board or commission. 
(k) (-j-) "Medi zion". A voluntary negotiating process in which parties in a dispute mutually select a neutral mediator to assist them in jointly exploring and settling their differences, culminating in a written agreement which the parties themselves create and consider acceptable.

(1) (-k-) "Non-Conforming Development". Activities, ses, buildings, structures, lots or improvements lawfully existing at the time of adoption or amendment of a zoring ordinance and not in conformity with the provisions of such ordinance.

(m) (-z-) "Overlay District". A district established in a zoning ordinance that imposes specified requirements in addition to thoses otherwise applicable in the districts or parts $f$ districts on which the overlay district is superimposed.

(D) "Passive solar energy system." A solar energy system that uses natural and architectural components to collect and store solar energy without using any external mechanical power.

(0) (-m-) "Planned Development". A development where a specified minimum area of land is planned and deveioped as a single entity. A planned development may accomodate residential, commercial, industrial, and other uses separately or jointly, and may include one or more public or quasi-public sommon area.

(p) (-n-) "Residential Ciuster Development". A development where a specified minimum rea is developed according to a plan at specified densities as a complex of single or multiIumily housing types in more than one structure with one or more common open space areas, designed to serve the development. 
(q) (-0-) "Rocky Soils". Land having more than one

percent of the surface area made up of exposed bedrock or soils too thin over bedrock for use: these include but are not linited to land mapped by the Soil Conservation Service, U.S. Department of Agriculture as Canton and Charlton fine sandy loams, very rocky; Canton-Charleton-Rock outcrop complex; or rock outcropCanton complex or rock outcrop.

(r) (-p-) "Slowly -ermeable soils". Land characteristically having fragipan substratum layer whose estimated permeability rate is less than two-tenths (0.2) inches per hour, including but not limited to land mapped by tho suil conservation service of the U.S. Department of Agriculture as soil series Birchwood, Broadbrook, Mansfield, Newport, Paxton, Pittstown, Poquonock, Rainbow, Ridgebury, Stissing, Whitman, and Woodbridge.

(s) "Solar Access". The ayailability of solar radiation to a solar collector: pro ating this access implies greventing shadows from yegetation, juildings or other obstructions from shading the solar system.

(t) "Solar collector". A device, or combination of devices, structure, or part of a device or structure that uses incident solar radiationlsolar energy falling upon a given surface areal into thermale mechanical, chemicale or electrical energy.

(u) "Solar energy". Radiant energy Jirect, diffuse, and reflectedl received $\mathrm{f}_{\text {; }} \mathrm{m}$ sun.

(v) "Solar energy system", A complete design or assembly consisting of a solar energy collector, an energy storage facility (where used), and components for the distrib= 
ution of transformed energy the the extent that they cannct be used jotntly with a sonventional energy system.

(w) (-q-) "Steep Slopes". Land for which the average slope exceeds ten ( $:$,) percent, that is, a change of ten (10) feet vertically pf: one hundred (100) feet horizontally, or such grade as is specified in a zoning ordinance.

(x) "Structure." Anything constructed or installed or portable that requires for normal use a location on a parcel of land. This includes any moyable structure located on land which can be used either temporarily or permanently for housinge business, commercial, agricultural, or office purposes. It also includes fences, billboards, poles, pipelines, transmission lines, and advertising signs.

(y) (-t-) "Transfer of Development Rights". The transfer of development potential or development density from one parcel of land to another. The development right, one of many property rights, is severed from the first or "sending" parcel and attached to the second or "recipient" or "receiving" parcel. Land owners in sending areas give up their development rights and are compensated by land owners in the "receiving" areas who benefit from a density bonus. The parcels of land may or may not be contiguous and the sending and receiving land owners may or may not be the same person or persons.

(z) (-s-) "Unnecessary hardship". An exceptional physical condition that is unique to a parcel of land or a structure and not generally characteristic of the district or surrounding area, that is not the result of any action or failure to act by an appellant or any current or prior owner of the land or structure, 
and which would cause total deprivation of all beneficial use of the land or structure if the provisions of the zoning ordinance applicable thereto were strictly enforced.

(aa) "e-) "Variance". Permission to depart from the literal requirements and provisions of a zoning ordinance adopted in accordance with the provisions of this chapter.

(ab) (-t-) "Wetland, Coastal." A salt marsh bordering on the tidal waters of this state and contiguous uplands extending no more than fifty yards inland therefrom as defined in section 2-1-14 of the General Laws.

(ac) (- -) "Wetland Freshwater". A marsh, swamp, bog, po.d, river or stream flood plain or bank, area subject to flooding or storm flowage, emergent or submergent plant community in any body of fresh water, or area within fifty feet of the edge of a bog, marsh, swamp, or pond, as defined in section 2-1-20 of the General Laws.

(ad) (-w-) "Zoning District liap". A map or maps, and such written description, which delineates the boundaries of zoning districts and are part of the zoning ordinance.

(ae) $(-x-)$ "zoning Ordinance". A city or town ordinance which sets forth regulations and standards relating to the nature and extent of the uses and/or dimensions of land and of buildings and other structures theron adopted in accordance with the provisions of this chapter.

45-24-28. General Purposes of Ordinance.- For the purposes of promoting the public health safety, morals, and general welfare, a zoning ordinance shall provide for the implementation of 
land use and development policies, gcals, and patterns contained in the city or town comprehensive plan. In order to accomplish these purposes, a zoning ordinance may:

(a) provide sufficient space in appropriate locations for a range of uses and intensi ies of use appropriate to the character and needs of the ci-y or tarn;

(b) relate the use or land to its physical characteristics and capabilities and to the availability of public facilities and services;

(c) promote the conservation of energy, open space, natural resources, and significant natural features;

(d) control air, water, groundwater and noise pollution, soil erosion, and sedimentation; provided that nothing contained herin shall supersede the statutory authority of agencies of state government pertaining to these matters.

(e) enhance the cultural and historic character of the city or town;

(f) preserve agricultural land;

(g) facilitate the adequate and economic provision of and/or protect substantial public investment in transportation, water, sewage disposal, schools, recreation, open space, and other public requirements;

(h) promote a choice of housing opportunities for all economic social groups;

(i) secure safety from fire, flood, and other dangers from natural or man-made disaster;

(k) provide adequate light and air; and

(1) promote the establishment of population densities and 
concentrations that will contribute to the well-being of persons, families and neighborhoods and prevent the overcrowding and/or underutilization of lanc..:

(m) encourage the use of rf newable resources.

(n) promote energy efficient patterns of land devel= epment. 10

(0) protect solar access for solar energy systems.

45-24-29. Contents of Ordinance.

(a) [No Change]

(b) A zoning ordinance may include provisions for:

(1) Limiting and restricting buildings and other structures to specified zoning districts and regulating said buildings and other structures according to tneir type and the nature and extent of their use and regulating the nature and extent of the use of land for housing, business, commerce, industry, open space, or other use.

(2) Restricting buildings, structures, land uses, and other development by performance standards or other requirements related to air and water and groundwater pollution, noise and glare, soil erosion and sedimentation, and/or availability and capacity of existing or planned public services.

(3) Reguiating the height, number of stories, - d size of buildings and structures and the dimensions, size, cf buildings and structures and the dimensions, size, building coverag?, cind layout of lots or development areas. 
and regutating aeeess to suntight for sotat energy

systems-

(4) Specifyir flo, area ratios and ocher ratios and techniques govern-ng the intensity of use and the provision of adequate light and $a i r$.

(5) Designating requirements for open space, yards, courts and the density of population.

(6) Designating flood plains or flood hazard arsas and significant natural areas, and controlling development in these areas.

(7) Providing standards for and requiring the provision of adequate and properly designed physical imroveme $s$ including off-street parking areas, off-street loading eas, lighting, fencing, landscaping and others in connection with any use of land, building or structure.

(8) Restricting and limiting development and land use in areas where such development is deemed to create a hazard to the public health or safety.

(9) Controlling extractive $i$ dustries and earth removal activities, and requiring s-storation of land after such activities.

(10) Regulating sanitary landfill.

(11) Regulating signs and b: Iboards, and other outdoor advertising devices.

(12) Designating airport hazard zones under the provisions of Chapter $1-3$ of the general laws of Rhude Island, 1956, as amended, entitled "Airport Zoning", and 
Enforcement of said hazard zones under the provisions establisted in said ge erć. laws.

$$
\text { Designating areas of historic, archaeological, }
$$

or architectural value and regulating development in such areas under the provisions of Chapter 45-24.1 of the general laws of Rhode Island, entitled "Historic Area Zoning".

(14) Providing standards and requirements for the regulation, review, and arnroval of any site plan in connection with any use of lana, building, or structure designated in a zoning ordinance.

(15) Authorizing ncreases in the permissible density of population or intensity of use as a condition for increased open space, housing for low and moderate income persons, traffic and pedestrian improvements, public facilities and other amenities. Such provisions in the zoning ordinance shall be specific as to maximum allowable densities of population or intensities of use and shall state specific improvements and amenities.

(16) Establishing a system for transfer of development rights within or between zoning districts designated in a zoning ordinance.

(17) Consolidating public hearings when more than one hearing would otherwise be required in considering a proposed amendment or development.

(18) Regulate solar collectors as accessory uses. 
45-24-30. Power of Council to Adopt-Conformity to Plan. No Change

45-24-31. Notice and Hearing Requirement.
(a)
[No Change]
(b)
[No Change]
(c)
[No Change]
(d)
[No Change]

45-24-32. Procedure for Adoption.

[No Change]

45-24-33. Review by Planning Board or Commission-Requirements.

(a) [No Change]

(b) May include, as appropriate, a demcnstration of recognition and consideration of:

(1) potential soil erosion problems;

(2) potential problems of building on steep slopes;

(3) the hazards of flooding;

(4) the difficulty of development in rocky soils or imperfectly drained and slowly permeably soils;

(5) the values and dynaric nature of coastal ponds and shoreline features and the impact thereon of the proposed ordinance or amendment;

(6) the values of retaining forest land or agricultural land.

(7) the potential for groundwater pollution from certain types of development in excessively permeable soils;

(8) the values of fresh water wetlands systems; 
(9) the values of compatible land uses, stability of land uses, and harmony with neighboring uses; and

(10) the availability and adequacy of public facilities and services affected by or required to serve the proposen development and the area in which it may be located.: and

(11) the yalue of protecting and providing solar access for the purpose of utilizing solar energy.

45-24-34 Land Development Projects.

(a) [No Change]

(b) [No Change]

(c) In regulating land development projects, an ordinance adopted pursuant to this chapter may include, but is not limited to, regulations governing the following:

(1) A minimum area or site for a land development project:

(2) Uses to be permitted within such a development;

(3) Ratios of esidential to non-residential uses where applicable:

(4) Maximum density per lot and maximum density for the entire development with provisions for adjustment of applicasle lot density and dimensional standards where open space is to be permanently set aside for public or common use: where the physical characteristics, location, and/or size of the site require such adjustment or where the 1ocation, size and type of housing units, commercial, indus- 
trial or other uses require such adjustment;

(5) Roads, driveways, utilities, parking and other

facilities, and may distinguish between those intended to remain in private ownership or to be dedicated to the public, provided that any stch facilities which are intended to be dedicated to the public shall meet applicable requirements of any ordinance and regulations adopted pursuant to Chapter 45-23 (Subdivi ion of Land) of the General Laws of Rhode Island.

(6) protect solar access for proposed or potential solar energy systems in the development. 45-24-35. Non-Conforming Development.

[No Change]

45-24-36. Modification of Non-Conforming Development.

[No Change]

45-24-37. Elimination of Non-Conforming Development by Amortization.

[No Change]

45-24-38. Enforcement of zoning Ordinance.

[No Change]

45-24-39. Zoning Board of Review-Establishment.

[No Change]

45-24-40. Powers of Board of Review.
(a) [No Change]
(b) [No Change]
(c) [No Change]
(d) iNo Change]
(e) [No Change] 
(f) In gra.ting a variance under subsection (c) of this section, or in permitting a special exceptio under subsection (b) of this section, the zoning board review may apply such special conditions to the grant that may in the opinion of the board, be required to maintain harmony with nelghboring uses and promote the cbjectives of the comprehensive plan and zoning ordinance. Such special conditions may include, but are not limited to, provisions for:

(1) minimizing idverse impact of the development upon other land, including the type, intensity, and performance of activities;

(2) controlling the sequence of development, including when it must be commenced and completed;

(3) controlling the duration of use of development and the time within which any temporary structure must be remover:

4) assuring satisfactory insta'lation and maintenance of required public improvements;

(5) designating the exact location and nature of development; and

(6) establishing detailed recoras by submission of drawings, maps, plats, or specifi cions.i and

(7) providing protection of solar access for all solar energy systems and structures.

45-24-41. Expenses of Zoning Board of Review-Fees. [No Change]

45-24-42. Appeals and Applications to Zoning Board of Review. 
[! Change]

45-24-43. Stay of Proceedings on Appeal to Zoning Boa 3 of Review.

[No Change]

45-24-44. Public Hearing by zoning Bcard of Review.

[No Change]

45-24-45. Records of Board.

[No Change]

45-24-46. Mediation Option.

[No Change]

45-24-47. Appeals to Superior Court.

[No Change]

45-24-48. Priority in Judicial Proceedings.

[No Change]

45-24-49. Penalty for Violation.

[No Change]

45-24-50. Judicial Aid in Enforcement.

[No Change]

45-24-51. Reimbursement to City or Town.

[No Change]

45-24-52. Creation of Vested Rights or Encumbrances.

[No Change]

45-24-53. Severability.

[No Change] 


\section{Explanation of Amendments}

The Legislative Findings and Intent section of The State zoning Enabling Act is a statement of policy and goals set forth by the legislature. It can provide guidelines to the communities within the state on a policy for encouraging the use of solar energy in their zoning ordinance. Therefore, item (15)" to provide protection of solar access to solar energy systems" has been added in order to set forth the goal of protection of solar access in the Act. With this new section (15) added to the Act, a policy of providing solar access to solar energy systems has been set forth for the communities to follow. The section also provides the intent of the Act for purposes of judicial review. Seven definitions have been added to section 45-24-27. These definitions are needed by communities that are developing either solar energy resolutions or solar access ordinances because these defi?itions refer to concept; and items that are paramount to any discussion of solar energy. These new definitions narrow the scope of the Act by specifying for each community exactly what the meaning and implications are of protecting solar access. These new definitions also broaden the scope of the Act by adding the "world" of solar energy. The substance of these definitions are discussed in detail in Chapter One: "Basics of Solar Energy for the Land Use Planner."

The General Purpose of Ordinance section (45-24-28) provides possible land use policies which may be included in the zoning ord:nance. Amending the purpose of the ordinance to include 
specific reference $t$ solar energy is an important step to promoting and encouraging the use of solar energy systems. Item (k), as with traditional zoning ordinances, states: "to provide adequate light and air." This provision merely hints at protection of solar access. Three additional items have been added to carry forth further the concept of providing protection of solar access. Items (m) "encourage the use of renewable resources;" and (n) "fromote energy efficient patterns of land development", have been added to this section for the purpose of extending the perceived meaning of item $(k)$. Item (o) "protect solar ccess for solar energy systems" specifically focuses on the protection of solar access which has been described as a purpose of the ordinance in items (m) and $(n)$.

The Contents of Ordinance sec $=$. on (45-24-29) states exactly what may be provided for in the local ordinance. While many active and passive sy tems maybe included within a building, some energy systems may consist of detached collectors. Unless these detached collectors are allowed as a permitted accessory use, they will be prohibited. In order to promote the use of solar energy systems, item (18) allows for these detached collectors to be a permitted accessory use.

In the Review by the Planning Board or Commissions Requirements section (45-24-33), item (11) has been added to reinforce the importance of soiar energy and the protection of solar access. The protection of solar access is viewed by this author to be of the same magnitude of importance as the previous ten items in this section, which include wetland protection; 
the problems of soil erosion; and the hazards of flooding.

The Land Development Projects section (45-24-34) is concerned with large-scale developments and the issues related to such a project. Land development projects are phased projects that in the future, as fossi' Euels become increasingly scarce, will need to depend on solar energy. This is an ideal forum to assure that solar acce-s is protected because in involves new development on "virgin" land. It is much easier to provide protection of solar access when there are o larje, tall, older buildings to contend with. Alio, in a land development project, issues such as density, driveway and road location are regulated. These are issues which can effect the protection of solar access, and can be regulated in such a manner that they complement solar access protection.

The Power of Board of Review section (45-24-40) states the provisions for special conditions which the zoning board of review may apply to granting a variance or permitting a special exception. It states that these special conditions may be applied in order to ". . maintain harmony with neighboring uses and promote the objectives of the comprehensive plan and zoning ordinance." Amended objectives sf the zoning ordinance (45-24-29) inclucie encouraging the use of renewable resource; promoting energy efficient patterns of land development and protection of solar access for solar energy systems. Therefore item (7) "providing protection of solar access for all solar energy systems and structures," has been added as a special condition which ma be applied by the zoning board of review because it 
conforms to the amended objectives of the zoning ordinance. It also reinforces the importance of providing pro.ection of so. ir access in new developments.

\section{Conclusion}

The first step toward assuring a sound solar energy policy is to amend the state zoni.ig Enabling sct to irclude provisions for protection of solar access. As this is iccomplished at the state level, it sets forth guidelines, regulations and incentives to "trickle-d $z "$ to the local level if government. This "trick'ing-aown" can appear in various forms in different methosology. All of these methods can be implemented simultaneously, and are not exclusive of each other. Theis meaning and intent of a sound solar enerfy policy is strenghtened if they are used to complement each other.

One method is to revise the local zoning ordinance to include provisions for protecting solar access. The revised local zoning ordinance can include provisions similar to those in the amended State Zoning Enabling Act in Chapter Three. Appendix I contains revisions to the zoning ordinance of Foster, Rhode Island, to include provisions for solar access protection.

Appendix III contains a second method which can be complementary to an amended zoning ordinance: A Town Energy Resoulution. This resolution is a policy which supports a community's efforts to encourage solar energy use.12 According to its author, it 
- - sets forth a general policy goal of "protecting future potential for solar energy use" and directs both the planning board and the building inspector's office to incorporate solar considerations into their respective duties.13

This resolution suggests that the planning board amend its comprehensive plan to encourage energy efficiency.

This suggestion leads to a third type of methodolgy which could strengthen a sound energy policy in a town. Appendix IV contains the table of contents and list of tables for an energy management plan for the town of Foster, Rhode Island. Plans for nine Rhode Island cities and towns have been completed as the product of a grant from the U.S. Department of Energy and The Farmers Home Administration through a consortium including the Rhode Island League of Cities and Towns; New England Innovation Group; and the Department of Community Planning at The University of Rhode Island.

These plans contain ar. in jentory of each towns energy use in the municipal; residential; industrial and commercial sectors.. It also contains scenarios for the future if present energy usage is constant. An inventory such as the one utilized in the energy management plan is a useful means of developing the long and short term goals for promoting energy efficiency in all towns.

A fourth method is illustrated in Appendix $V$. This is An Ordinance Declaring Solar Rights, for Taos, New Mexico. This ordinance, which is separate from the zoning ordinance, designates the specific hours of the day in which solar access is to be protected. This ordinance, complemented with a zoning ordinance that provides protection of solar access would provide 
the backbone for a sound solar energy policy in a town.

In conclusion, it has been illustrated that solar energy is becoming a viable, economically sound method of heating and cooling buildings. If its use is to flourish and continue, the land use policies in our country must promote and encourage the use of solar energy. As planners, we are given the opportunity to remove the impediments and barriers. We must take hold of this opportunity by fully utilizing the land use tools available to us. 


\section{ENDNOTES}

1

Department of Commerce, Standard State zoning Enabling Act (1926); Anderson, supra note 36301.01 .

2

William a. L. rence and John H. Minan, Legal Aspects of Solar Energy (Lexington: Lexington Books, 1981), p. 54.

3

American Planning Association, Protecting Solar Access for Residential Development: A Guidebook for Planning officials, (Washington: U.S. Government Printing office, 1980), p. 47.

4

ibid.

5

Cynthia Collins and Lori Heise, Community Land Use Toels for Encouraging the jse of Solar Energy: A Tool Rit for Nine Rural Towns, (Providence: RI League of Cities and Towns, 1982) p. 7 .

6

City of Ashland, Chapter 18.70 "Solar Access" 1982.

7

ibid.

8

ibid.

9

ibid.

10

Collins; Cynthia, Communits: Land Use Tools for Encouraging the Use of Solar Energy: A Tool Kit for Nine Rural Towns, p. A-2.

11

ibid. p. A-11 - A-12.

12

ibid. A-1.

13

ibid. 
APPENDIX I 
ST A TE OETRHODE ISLAND

84-S 424

IN GENERAL ASSEMBLY

JANUARY SESSION, A.D. 1984

A N A $\subset$ T

RELATING TO ¿ NG

Introduced Bv: SEnator Gannon, Forte and Bevilacqua

Date Introduced: February 28, 1384

keferred To: Committee on Judiciary

It is ena.-ed by the General Assembly as follows:

1

2

3

4

SECTION 1. Chapter 45-24 of the General Laws entitled "Zoning Ordinances" is hereby amended by auding thereto the following sections:

45-24-24. Title. - Sections 45-24-26 through 45-24-53 of the Rhode Island general laws shall be known as the Rhode Island zooing enabling act of 1984 .

45-24-25. Continuation of ordinances. Supercession - Relation to other statutes. - (a) All lawfully adopted zoning ordinances shall be brougti into conformance wit: this chapter by July 1, 1987. Each city and cown shall review the zoning ordinances and make such amendments or revisions as are necessary to bring it into conformance with this chapter.

(b) Sections 45-24-1 through 45-24-23 of this chapter and all special zoning eabling acts are repealed effective July! 1987 . Ail provisions of zoning ordinances adopted under authority of the provi- 
sions of sections 45-24-1 through $45-24-23$ or of any special act repealed hereby shall become null and void as of July 1,1987 unless amended so as to conform to the provisions of this chapter.

(c) All zoning ordinances adopted under authority of sections 45-24-1 through 45-24-23 of this chapter or any special zoning enabling act that is in effect on the date of enactment of this act shall -emain in full force and effect until the date specified in subsection (b) of this section, unless earlier ar anded or repealed.

(1)

(1) Tille 45, chap ar 24.1 of e general laws of Rhode Island, entitled "historic area zoning", and tle 1 , chapter 3 of the general laws of Rh .e Island, entitled "airport zoning" shall not be superseded by this chapte:. Provioed however, any appeal to the superior court pursuant to title 1 chapter 3 of the general laws of Rhode Island, entitled "airport zoning", il e taken in the manner provirad in sect:on $45-24-27$ of the genera! laws.

$\pm 5-24-26$ Legislative tindings and intent. -. (a) The general ussemty inds that the land of Riode Island is a finte natural. resource that inust be carefuily maragei in order to: (1) accommodate needs for land; (2) recogaize the vas" ng capability of land to support developinent; (3) prevent haphazars scatiaring of urbaa growth throughout rural areas, which result: $n$ increased service costs and loss of open space; (4) locate development with consideration of the required level and cost of public services; (5) meet needs for energy, water, and aste disposal; (6) forestall preemption of the few sites that are suitat: for certain essential facilities by uses witb less demanding rejucements; (7) matigace problems in finding acceptable locations f: essential facilities with important social, ecorsmic or environmental impacts; (8) ensure bousing choice; (9) discourage conversion of productive agricultural land and forests to other uses; (10) protect valuable natural resources; 1) avold construction in hazardous locacions; (12) avert damage to historic, archaeological. and architectural lantmarks: (13) give attention to design and visual 
quality; and (14) reduce expenditure of effort by comanities compet. ing for land uses that pay high property taxes and wake few dewands on public services.

(b) The general assembly further finds that: (1) the present zoning enabligg statuces were largely enacted in 1921 ; (2) the character of land development and related public policies have changed substartially in the intervening years; (3) many cities and cowns have found that the current zoning enabling stacutes are no longet an adequate basis for regulating the use of land and providing for modera date, and thus do not take into account the requirement that cities and towns adopt a comprebensive plan pursuant to chapter $45-22$ of the general laws; and (5) a substantial updating and revision of the statutory zoniag enabling authority is required to meet these changed conditions.

(c) It is therefore found that preparation and implementation of comprehensive plans and zoning ordinances that address these problems and needs is necessary in order to protect the public health, safety, and general weifare and in order to secure the rights of the people of Rhode Island to the use and enjoyment of the natural resources of tbe state; to allow the general assembly to fulfill its duty to provide for the conservation of the natural resources of the state; and to provide for balanced economic growth in the state.

(d) Therefore, it is the incent of the general assembly:

(1) That the zoning enabling authority contained berein provide all cities and towns with adequate opportunity to address current and future commonity and statewide needs;

(2) That the zoning enabling auchority contained herein provide cities and towns with a clear definition of the relationship betweed and the respective functions of their planning and zoning activities; (3) That the zoning enabling authority contained heresn empower cities and towns witb the capabilit; to establish and enforce stan- 
1 dards and prc edur for the prop:r ranageneat of lacd as a natural 2 resource an o emnisy con mporary concepts, metbods, and criteria in 3 regulating tue type, intensity, and arrangenent of land use, ard pro4 vide authoraty to enploy new concepts as they may become available and 5 feasible;

6 (4) That these be provided for in a manner which will provide 7 maximum continuity for, and the least distuption to, current zoning ordinanses, and allow for the adoptioa of a zooing ordinance pursuant to this crapter, Jurang which time existing zoning ordinances adopted pursuant to the general or public laws may be continued in full force 
(d) "Special exception". A conditional use peraitted is a particular zoning district only upon showing that such use in a specified location will comply with all the conditions and standards for the location or operation of such use as specified in a city or tow zoning ordinance and authorized by the zoning board of review.

(e) "Excessively permeable soils". Soils which have characteristics which, due to a celative fast movement of water in the soil, may cause pollution of groundwate These inclide but are not limited to iand mapped by tbe soil conservalion service, United States department of agriculture, as the following soil series: Agawam, Bridgebampton, Deerfield, Enfield, Gloucester-Bridgehampton, Gloucester-hinckley, Hinckley, Hiockley-Enfield. Lippit, Merrımac, Ninigret, Quonset, Raypol, Scarboro, Sudbury, Tisbury, and Windsor.

(f) "Family". (1) One or more persons occupying a single bousekeeping unit tho are related by blood, narriage, or adoption, or where tbere is a le 11 responsibility for custody or care, and any domestic servants thereof, (2) not more than three adult persoos who are not so reisted occupying a single housekeeping unit or (3) a community residence licensec iy the state for six or fewer retarded children or adults or not wore than eight mentally disabled perions.

(8) "Eloodplains" or "flood hazard area". An area that has a one (1) percent or greater change of inuadation in any given year, ss delineated by appropriate federal or state agencies, or by the aity or cown, usiog accepted hydrologic and engineering practices.

(b) "Imperfectly srained soils". Land for which the estimated seasonal bigh water table level is less than four (4) feet from the ground surface, including but not limited to the following moderacely-well drained, poorly drained, and very poorly drained soil series mapped by the soil conservation service, United States iepartment of agriculture-Adrian, Birchwood, Carlisle, Deerfield, Ipswicb, Leicester, Mansfit. Matunuck, Ninigret, Plttstown, Podunk, Rainbow, Raypol, Ridgebury, Rumney, Scarboro, Scio, Stissing, Sudbury, Sutton, Tisbury, Walpole, Wapping, hicman, and hoodbridge. 
(i) "Land development project". A pro, it in which one or more lots, tracts or parcels of land are to be ieveloped as a coordiated site : or a complex of activities, units or structures, including, but not limited to, residential cluster develoomeat, and planned development, when permitted by a city or town zoning ordinance and authorized by the planning board or comission.

(j) "Mediation". A voluntary negotiating process in which parties in a jispute mutually select a neutra rediator to assist tbem in jointly explising and settling thelr differences, culminating in a written agreement which the parties ts.....elves create and consider acceptabis.

(k) "Ton-corforming development". Activities, uses, buildiogs, structures, lots or improvements lawfully existing at the time of adcption or amendment of zoning ordinance and not in conformity witb the provisions of such crdimine.

(1) "Overlay district". A district established in a zoning ordinance that imposes specified requirements in addition to those otberwise applicable in the districts or parts of districts on which the overlay distriet is superimposed.

(m) "Flanged development". A development where specified mintmum area of land is planned and devel, od as a 3 .e enticy. A plan A davelopment may accomodate : identia: nercial. industral, and uiter uses separately cr jointly, and may inclucs one or more public or quasi-public common areas.

(n) "Residential cluster development". A development where a specified manimum drea is developed acco:ding to a plan at specified densities as a complex of single or multi-family housing units or a combination of housing types in more than one structure with one or more common oner space areas, designed to serve the deve opment.

(0) "Rocky" soils". Land having more than one (l) percent of the surface area inade up of exposed bedrock ir soils too thin over bedrock for use: trese include but are not limited to land mapped by the soll 
conservacioa service, United states departengt of egriculture as

2 Cancos and Cbarlion fine seody loans, very rocky,

3 Canton-Charleton-Ror outcrop complex; or rock outcrop-Canton complex

4 or rock outcrop.

(p "Slouly permeable soils". Land characteristically having a fragipan substratue layer wh-se estamated permeability race is less than two-tentbs $(0.2)$ inches per hour, including but not liaticed to land mapped by the sill conservation servace of the United States departmeat of agriculture as soil serses Birchwood, Broadtrook, Mansfield, Nemport, Paxton, Pittstowa, Poquonock, Rainbow, Ridgebury, Stissing, Whitman, and Woodbridge.

(q) "Steep slooes". Land for which the average slope exceeds ten (10) percent, that is, a change of ten (10) feet vertically per one nundred (100) feet borizontally, or such grade as is specified in a zoning ordinaoce.

(r) "Transfer of developwent rights". The transfer of development potential or development density from one parcel of land to another. The development right, one of many property rights, is severed frow the first or "sending" parcel and attacbed to the second or "recipient" or "receiving" parcel. Land owners ia sending areas give up tbeir development rights and are compensated by land owners in the "receiviag" areas who benefit from a density bonus. The parcels of land way or may not be contiguous and the sending and receiving land owners any or may not be the same person or persons.

(s) "Unoecessary hardship". An exceptional paysical condition that is unique to a parcel of land or a structure and not generally characteristic of the district or surrounding area, that is not the result of any action or failure to act by an appellant or any current or prior owner of the land or structure, and which would cause tota: deprivation of all beneficial use of the land or structure if the proviszons of the zoning ordinance applicable thereto were strictly enforced. 
1. (t) "Variage". Permissioa to depart froa the literal require2 weats and provisions of zoning ordinance adopted in accordance with 3 the provisions of thas chapter.

(u) "Wetland coastal". A salt earsh bordering on the cidal waters of this state and contiguous uplands extending no more than fifty (50) yards inland therefrom as defined in section 2-1-14 of the general luws.

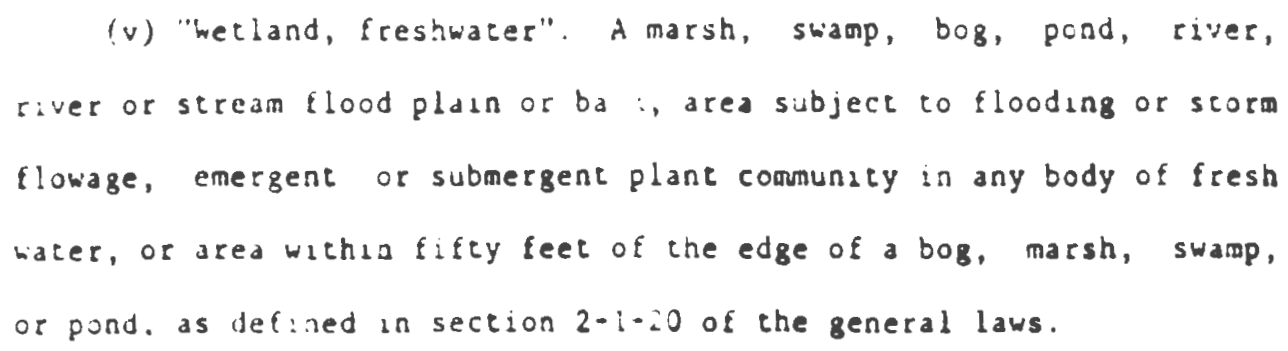


1 (5 promote the cooservation of energy, open space, astural

(d) control air, water, groundwater and noise po stion, soil erosion, and sedientation; pr.aded that nothing contasned herein shall supersede the statucory authority of acencies of state govera-

(f) prosirve incultural land;

(8) facilita e the adequate and econc- $c$ provision of and/or protect substantial public iavestment in transportation, water, sewage disposal, solid waste disposal, sc lols, recreation, opea space, and orher public requiremears;

(b) promote a choice ubousing opportunities for all economic and sociai groups;

(i) secure safety from tize, flood, and other dangers from aatural or man-made disaster;

(j) lessen traffic congestion;

(k) provide adequate light and air; and

(1) promote the esta.lishmeat of population deasities and coarentrazions that will contribute to the well-beiog of persons, families and neighborhoods and prevent che overcrowding and/or inderutilization ef land.

45-24-29. Concents of ordinance. -- (a) A zoaing ordinance sball fivic a city or town into districts, which may include overlay districas and specially planned areas, of $s$ number, stape, and area as deemed suited to carry out the purpos - E this chapter. Regulations shall be unifor for each land use or cype of building or structure within a district, but may differ from tbose in otber districts.

(b) A zoaing ordinance may iclude provisions for:

(1) Limitiog and restricting buzldings ad ocher structures to specified zoning districts and regulating said buildiags and otber 
1. St:uet ss according to theis cype and the racure and exteat of tbeis use and rezulacing the nacure and exteat of the use of land for bousing, business, commerce, industry, ope space, or ocher use.

(2) Restrictiag bulldings, structures, land uses, and ocher deve: pmenc by performance scaudards or ocner requirements related co ait and water and groundwater asll. n, noise and glare, soil erosion ard sejimetastan, andior audilability art capacity of existang or plancel pubiac servises angs and siluctures and the dimensions, size, building coverage, and layout of lots or jevelopment areas and regulating access to suniagt for s: : eneigy systems. - ecifying floor area ratios and other ratios and techniques z erang tile intenst:y of use and the provision of adequate ligbe and $a \cdot r$.

(6) Deslansthig flood plans or flood hazard jzeas and sugaificant hubja! arous, and controlling development in these areas. il lianding standards for and requaring the provision of adefiate ant prope:!y designed physical improvements iacluding off-street rarking alezi off-street loading reas, lighting, fencrag, lands.oping atil i! as in connection with iy use of land, bulidiag or seristi..

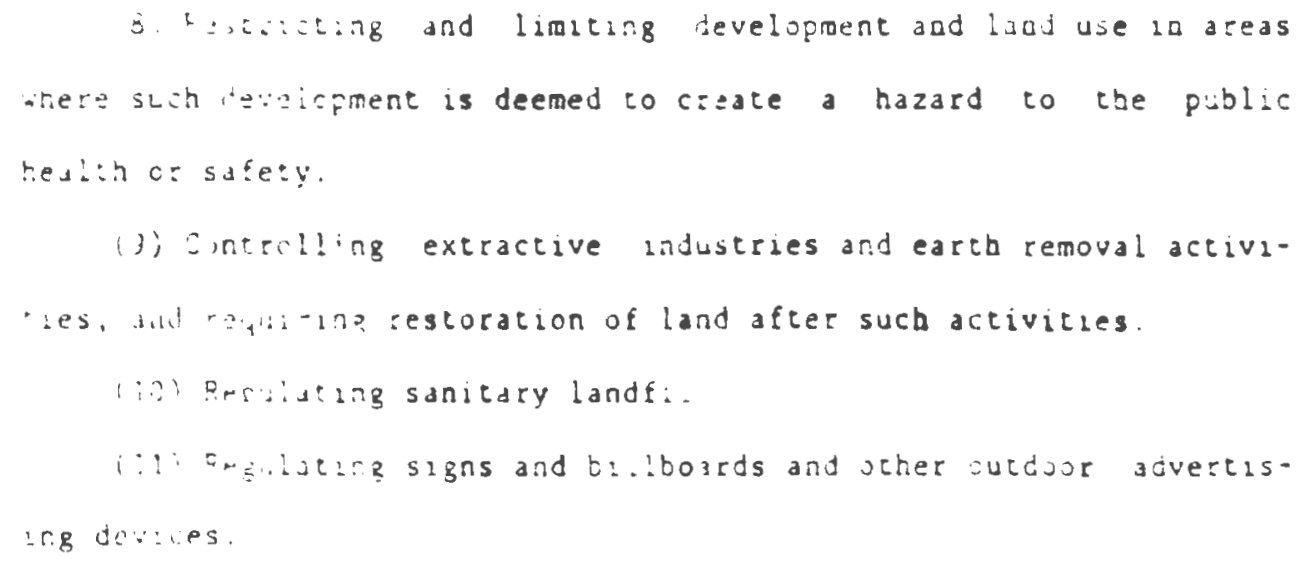



zones under the proviszons established in said general laws.

(1: Jesignaring areas of historic, archaeological or architectural va. and regulating development in such areas ander the provi-

(14) Providing standards ard requitements for the regulation, land, bulding or structure desig led in a zoniag ordinance.

(15) Auchorizing zacreases in the perwissible density of population or intessity of use as a condiciod for increased opeo space, housing for low and mojerate income persons, traffic and pedestrian anprovemeacs, public facilities and otber amenities. Sucb provisions in the zoning ordiance shall be specific as to maximum allowable deasities of population or intensities of use and shall state specific improvements and amemizies.

(16) Establishing a system for transfer of development rights withia $=$ between zoning districts designated in a zoning ordinace. If onsolidating public neazings when more chan one heariag would ornerwise be required in considering a proposed amentment or deve lopment.

45-24-30. Power of council to adopt - Sonformity to glan. For the purpose of promotiag the pubiic bealch, safecy, morals and general velfare, acy or town council shall have the power, in accordance with the provisions of this cbapter, to adopt, amead or repeal, and to administer and eaforce a 200108 ordanace. Frovisions of a zoning ordinance may be set forth in text, maps, cbarts or other form. A zoning ordiance shall be ta general coaformity with the coaprehensive communicy plan of plan of land use which has beea adopted by the city or town planning board or commissioa and/or by the caty or town council under provisions of capter 45-22 of the general laws or of home rule or legislative charters. 
2 aance sha!l be adopted, ar. od or repealed uncil after a public bear- a as been hel. upon the quest: before the city or town coupcil wro sha first give dotice of suib public hearing by publication of 5 rot - in a newspaper of general circulation within such cities or

27 chres (3) we'lis before the hearing, which may lnclude the week the

:0 hearamz is to horeld, and wraten notice of the tame and place of

i: such hearing 3 . I the nature and purpose thereof shail be sent to all

:2 owners of real property whose property is located withan two hundred 
(200) feet of the arineter of the area proposed for change. Notice stall also be seat $b$ he clerk in any adjacent ciey or towa whose boundary lies within two hundred (200) feet or within the area proposed for change.

(2) Notification pursuant to this subsection shall not be repuired where subsection (b) (1) of tbis section 1 result in a require. Lo gotify cwenty (20) or more prope swners, or such greater aumber as may be specified in the ordinance provided that the required newspaper notice also include in addition to tbe iteas spect. fied in subsection (a) of this section, a wap showing the existing and proposed boundaries, zoning district boundaries and existing streets and coads.

(3) For purposes of this section:

(A) specific cbange in a zoring district map shall be defined as a change which alcses the location a the boundarics of a zoning district in a limited geographic area, or would result in a requirement to nor. fy fewer than the number of property owners specified in subsection (b) (2) o. this section;

(B) an owner if real property" is the owner of record as showa in the curreat recor.s of the city or town assessor as of the date of filing tbe propossl.

(c) Written not se of an amendweat to the ordinance whicb is comprebensive or geaeral ua atire siall not be required to be adiled to owners of real property located withia two hundred (200) fees of tbe perimeter of the area or areas proposed for change. Wiritten ootice shall be sent to the clerks of all adjaceat cities and towns and to tr.e statewide planaing program.

(d) Notwithstanding the provisions of section 45-24-23, tiec or town council may in approving zone change lisit such change to one (1) of the permitted uses in the zone to which the subject land is rezoned, and impose such limitations and condzions upon the use of the la. = as it deems necessary. The resfonsible city or town official 


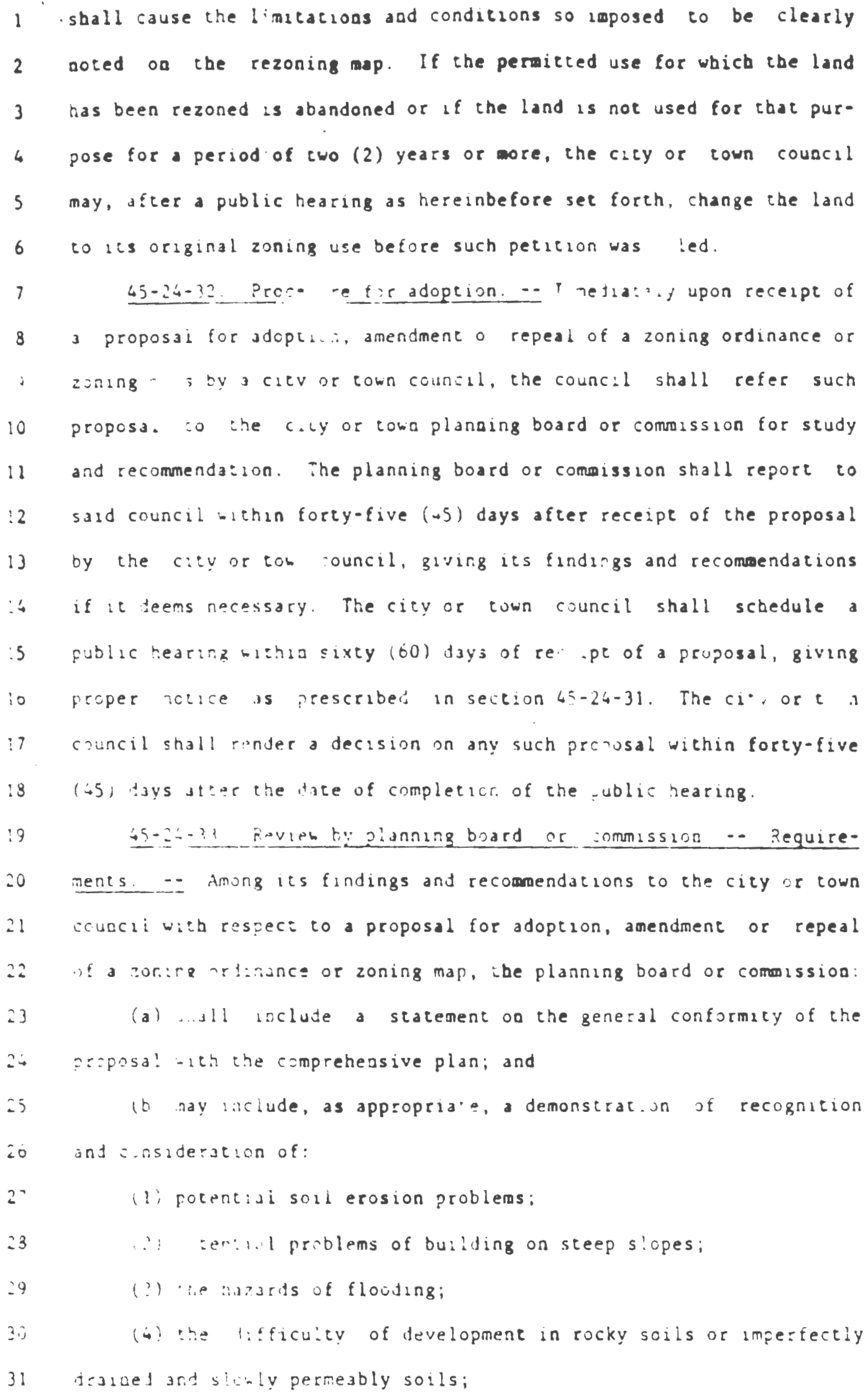


(5) the values and dyasic oature of coastal ponds and sboreline

features and te ampat tbereon of the proposed ordinance or asead-

(6) the valu:s of retaining forest land or agracultural land;

(7) the potential for groundwater pollution fron certain types of levelopment in excessuvely permeable soils:

(8) the values of fresh water -etlands systems;

(9) the values of comratible land uses, stat lity of land uses and harmony with nexgboorag uses; and

(10) the avalabilaty and adequacy of public facllities and services affected by or required to serve the prerssed developmeat and the area in which it may be located.

45-24-34. Land development proj- I. An ordiaace adopted pursuant $=0$ this chapter may include provisions and standards for and nuy establish districts fur or otherwise provide for the creatior of land development projec:s including residential cluster development ans planed development.

(a) A zoning oranance adopted pursuant to this chapter wbicb permits or allows for tae creation of a land development projecs stall raguire that any such project be referred to the city or town placoiag board or comassion for approval, in accordance with the procedures establisbed by chapter $45-23$ of the general laws of Rhode island. includiag those for appeal and judicial review, and with any ordinances or regulations adopted pursuant thereto, whether or aot the iand development coasticutes a subdivision as defined in said chapter 45-23.

(b) No such land development project shall be laitrated until a plan of same has been subwitted to said planning board or comission, a public hearing bas been held thereon, and approval has been granted by said planning board or commission. In reviewiag, hearing and deciding upon and development project, the city or tinn planniag board or comnissioo may be empowered to permit adjustments in density 
and dimensional requiremeots wibia such pro ect provided standards

2 Es: such adjustments are spec.fically described la tize $200 i n g$ ordi-

3 nance, and may be enpowered to apply such special conditions and

6 Stipulations to the approval as ay, ta the opiaion of the planaing

5 board or commission, be required to maintain harmony with neighboriag

(1) a minimum area or site size for a land development project; (2) uses to be permitted within such a development;

(3) raizos of resijential to nonresidental uses where applicable ;

(4) Taximum dins:l: per 10: and raximum density lor the entire Jevelopinent bita provisions for adjustmeat of applicable lot density ano dimensioral standarts where apen space is to be permanenty set aside tor public or common use; where the physical caracteristics, location, and, or slze of the slte require such adjustient or where the iocation, slae and lype of housing wists, commercill, industrial or other uses require sucb adjustment;

(s) roads, Jriveways, utblities, pasking and orber faclititles, 2 Jad may distangisb between those intended to remaln in private owner-

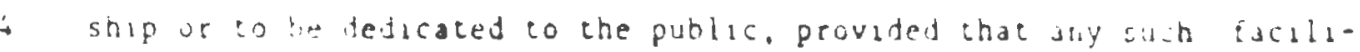
5 Les witich ale antended to be dedacated to the public sball neet

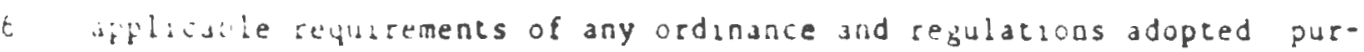
$i$ suant to chapter $45-23$ of the general laws of Rhode Island. 45-3-35. Noriconforming develogment. - Any eity or cown adoptang ar amend:riz d zang ordinance under this act shail make provision iherein for any tevelopment iabfully existing at the time of adoption or amentmec of the zonago ordinance, but which does not comply witb one or more frovisions of the orjinance is amendment as adopted. The 
1 zoniag ordianace hall perait contiauace of doncooforeing developent

2 wit ut change except that:

3 (a) Zoning ordinances may provide for modification of noac nforaing developent when such godification would result ia a greater degree of conformance co the zoning ordianace, as provided for in

(b) Zoning ordinances may provide for elimiation of nonconforming development by amortization, as provided for in section 45-24-37.

\begin{abstract}
20n: - ordiance ray provide that, in the event a nonconforming devel.
\end{abstract} opment is abeadoned or discontinued for a period of time stated in tbe ordiance, it sball not thereafter be esumed or reestablished except in conformace with the ordinance. A structure sball be considered abandoned if it is fully or partially denolished or otherdise physicaily altered so as to briag it into conformance, or ioto a grater degree of coaformance, with the ordinance. The use of structize or iand shall be considered discontinued if the activity or operation ceases, the predi-es are vacared, macbinery, equipment or flxtures are removed, or other action terminating tbe use is takea.

(b) A zoning ordinance way provide that, in the event that a nonconforming structure 0 . arovemeat is damaged by any meas or combination of means to an cent stated io the ordiance, as measured by appraised value, area occupied, or other appropriate measure, it stall not thereafter be rescored except in conformance with the ordinance.

(c) A zoaigg ordinance day provzde that aonconforming development may be wodified under all of the following conditioas:

(1) A perwit for a special exception, autborizing modification, must be issued by cte zoning board of appeals, following tbe procedure establisbed in tbis act and in the zoning ordiance.

(2) Aay modification shall bring the development more closely loto conformace with the zoning ordinance. Modifications autborlzed under this provision shall aot result in the ealargemeat or exteasion 
of aonconforming structure or iaproveneat or in cbange to a lad use that $i$ : First persicted ia a less restrictive zone than the previously exlsting land use.

45-24-37. Elimination of nonconforming development by amortiza:

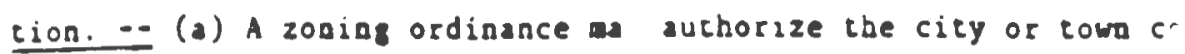

(b) A citv or town council shall utilize tbe following procedures a eimirztang anncorformine developwent by amortization: nonconforming develupmert. Upon the adoption of such a resolus.sa, 21 thereof submitted to the governing body within twelie (12) months 22 thereafter. The findings shall be filed with the planning board or is cown clerk, and shall be a mater of public record.

(1) The ci'v or town council shall by resolut on direct an appropriace city or cown agency or official to survey all or portions of : Je city or cown to determine the existence and location thereia of

(2) Sa:d planaing board or comission shall, withia one (1) year after receipt of such report, determine wrich, if any, of tbe nonconforming development set fortb in the report cause substantial detrament to the public welfare, adversely affect the surrouading area in H:ch it is located, or substantially impair the inteat and purpose of - comprehensive plan or zoniag ordinance. It shall forthwith there31 after notify the city or town cc acil of its findings. The council 32 shad thereupon conduct public hearings to determine which, if any, of 
the aosconforating developent set forth in the report of the planaing board or conassion should be ellainaced, followiag aotification by certified ail to the owaers of all properties to considered.

If the city or town council deternines that a aonconforming developane shall be eliminated by amortization, it shall establisb a tentative anortization period, sufficient to perait the property owner to recover the value or investment represented by the nonconforaing developmeat. In determining an amortization persod under this subsection, the city or town council shall also consider the urgency of the public purpuse requiring elimination, the detriment caused by the nonconforaing development, the probable extent of the ecos mic usefulaess of the nonconforming development and the cost of elimiation to the owner. its tentative detemiation and shall hold a public bearing thereon. amortization period and designate the date by which the nonconforming developmeat shall be brought into conformance with the zoning ordlance by modification or elimination.

(c) If the city or a council determines that a particular nonconforming development should not be eliminated at this tire, such deternination shall be binding for ap of five (5) years afte the date tbereof. Subsequent co this ptriod, the city or town council may again consider eliniation of the nonc aformag development following the procedures set forth in subsection $(0)$ of sectioa. ordinance shall designate the local official or agency charged with lts adsmiaistration and enforcement, including the issuing of any required peraits or certificates, keeping of records showing the compliance of uses of land, auchorizing comencement of uses or development under the provisions of the zoning ordinance, inspection of suspected 
as way be assigned in the ordiance. The zoniog ordianace shall also make provision for appointment of the zoniag eaforcenent official: agency, where enforcement duties and responsibilities are not charoed

4 to an existing official or sency.

(b) A zoning ordiance shall designate (1) the officer or agency responsible for malateance of the text ad map ano the offace or agency responsible for review of these at ieas. ole iatervals to Ldentify any changes aecessary.

45-24-39. Zoning board of review - Establishient. - (a) A zoning ordinance adopted pursuant to this chapter shall provide for creation of a zoning board of review and for appointment of members and organization of said board as specified in the zoning ordinance, or, in cities and towns with home rule charters or legislative cbarters, as provided in said charters.

t) Except as provided elsewhere in this section, or in a home-rule charter or legislative charter, the board of review shall consist of five (5) members, each to hold office for the term of five (5) years; provided, however, that the original appointments shall be made for terms of one (1), two (2), three (3), four (4), and five (5) years respectively. The chairman, or in his absence, the acting chairman, may administer oaths and compel the attendance of witnesses. linless otherwise provided by a home-rule charter or legislative charcer, the mavor of any city or the cown council of any town shall have the rignt to:

(1) name an auxiliary or sixtb (och) member of said board of reviey of said cily or town, as the case may be, who shall sit as an active member when and if member of said board is aable to serve at any hearing, upon request of the chairman of said board.

(2) name an addicional auxiliary or seventh (7th) member of said board of review, to sit as an active member when and if a member of sald board is unable to serve at any hearing upon request of the chairman of said board. 
(c) Zoning boards of revier in existeace od che effective date of adoption o: zonias ordinance under this chapter shall be considered to be the zoniag board of review for purposes of tbis chapter, and are exempt from provisions of this chapter respecting teras of originally appoiated neabers.

(d) Where not provided for ia the clty or town charter, the zoning ordinance shall specify qualifications for those zoning board members first appointed subsequent to adoption of a ordinance pursuant to this chapter, and procedures for filling vacancies in unexpired zerms. $4-24-40$. Powers of board of reviey. - Vote required for accton. The board of reviet shall have the following powers:

(a) To hear and decide appeals where it is alleged there is error io any order, requirement, decision, or determination rade by an

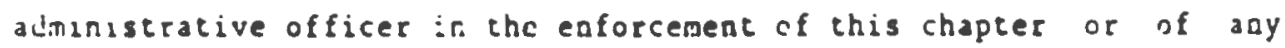
ordinance adopted pursuant hereto.

(b) To bear and decide special exceptions to the terms of the ordinance, upon which sucb board is authorized to pass under such ordinance.

(c) To aucborize upoo appeal in specific cases such variance in the application of the terms of the ordinance as will oot be cootrary to the public interest, where owing to special conditions a literal enforceneat of the provisioas of tbe ordinance will result in unecessary hardship, and so that the spirit of the ordinance shall be observed and substantial justice tone.

(d) In exercisiag the powers contasned in subsections (a) and (c) the board may, in conformity witb the provisions of this chapter, reverse or affirm wholly or partly or may modify the order, requirement, decision, or determination appealed frod and way make sucb order, requirement, decision or determination as ought to be made, and to that end shall have the powers of the officer frow whom the appeal was taken. 
(e) The concurriog vol, of three (3) mebbers of the board sball

be necessary to reverse any order, requirenent, decisioo or detereina-

3 tion of any such adanistrative officer, and the concurring vote of

i Cour (4) members of the board shall be required to decide 10 favor of

5 the applicant on any mate - witbio the discretion of the board upso

6 which it is requared to pass uader sucb ordioance or to effect any

7 variation in the application of such nedinance.

8 (f) In granciag variance under subsection (c) of tbis section, 7 or in permatiang a special exception under subsection (b) of this

10 section, the zoning board review may apply such special conditions to

11 the graat that may, in the opsaion of the board, be required to masn-

12 Lan harmony with neighboring uses and promote the objectives of the

13 comprehensive plan and zooing ordinance. Such special condations gay

14 inclise, but are nnt imbted to, pruvisions for:

15 (1) matinizing advelse mpact of the devo apmeat upor ollier lind

10 including lise iype, antensity, and performance of activaties;

(2) controlling the sequence of de-lopment, including when it

: 9 must be comenced and completed:

:9 (3) controiling the duration of use or development and tbe time $=0$ whan which any cemporary structure must be removed;

:1 (4) 3ssuring satisfactory installation and maintenace of re$2=$ quired public improvements;

ij (5) decignating the exact location and nature of develope $t$; an!

2 (0) escablishing decailed records by subrission it drawing,

25 maps, fiats, ur specifications.

i5 i5-24-41. Expenses of zoning board of review - Fees. - An ordi$\therefore$ nance adopted pursuant to this chapter may provide for the following:

28 (a) Reasonable fees to be paid by the appellant or applicant for

-9 the review and hearing of appeals and applications and recording of

ii) Lhe decasions thereon.

31 (b) The engugung of legal counsel, expercs and clerical assis-

3:- iance by the board to aid in the discharge of it: tuties. 


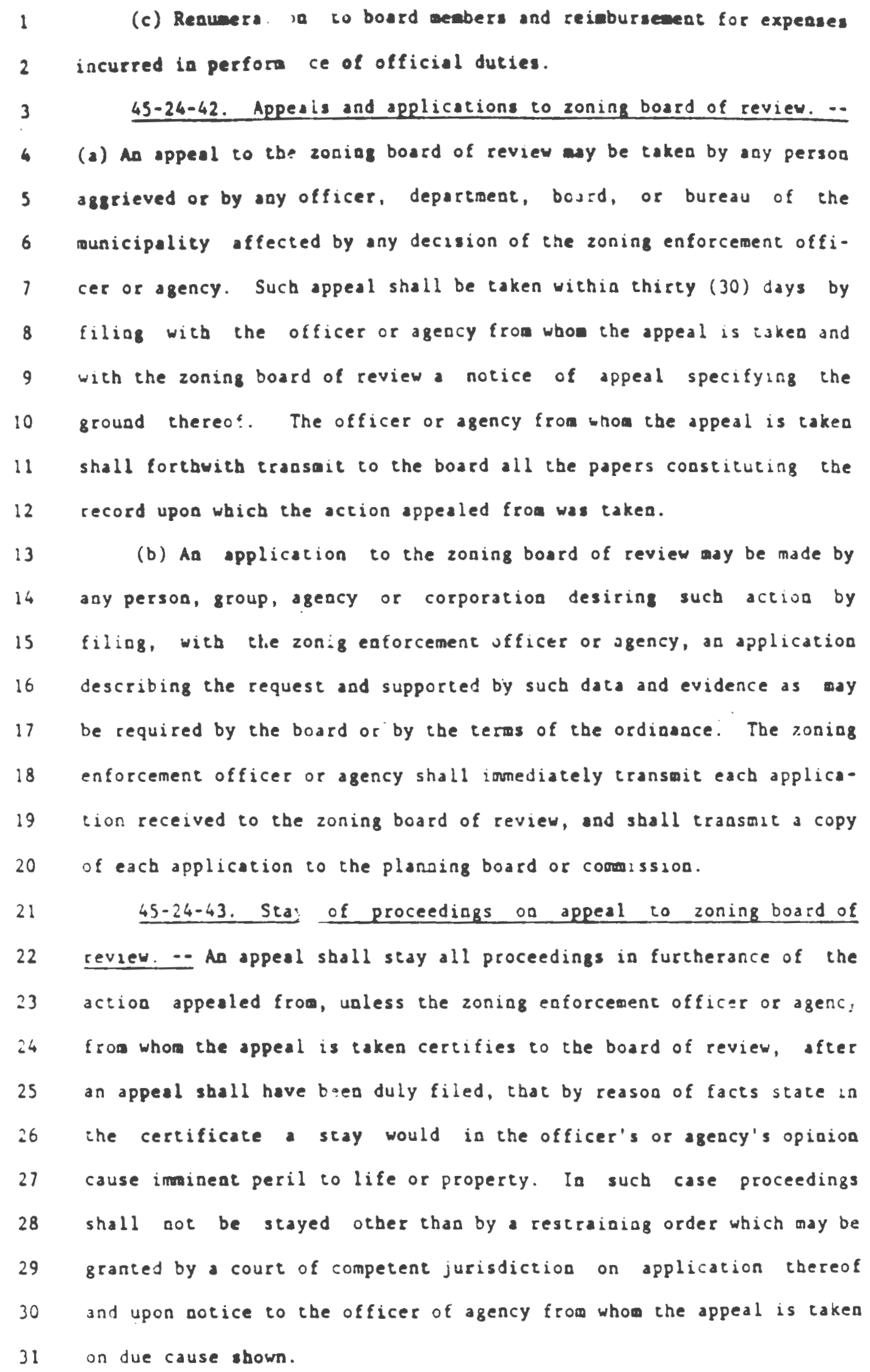

(c) Reaunera, in ro bourd meabers and reibburseneat for expenses incurted in perfor ce of official duties.

45-24-42. Appesis and applications to zoning board of review. --

(a) An appeal to the zoniag board of revieu ay be taken by any persoa asgrieved or by any officer, departmeat, bostd, or bureau of the municipality affected by any decision of the zoning enforcement officer or agency. Such appeal shall be taken withia thirty (30) days by filin with the officer or ageacy from whon the appeal is isken and with the zoning board of review a notice of appeal specifying the ground thereot. The officer or agency from nom the appeal is taken shall fortbuth crasait to the board all the papers constituting the record upon which the action appealed from was takea.

(b) An application to the zoning board of reviev ay be made by any person, group, agency or corporation desiring such action by filing, witb the zon:g eaforcement officer or agency, as application describing the request and supported by sucb data and evidence as ary be required by the board or by the terms of the ordinance. The zoning enforcement officer or agency shall iormediately cransmit each application received to the zoning board of review, and shall traasmit a copy of eacb application to the planaing board or cormissiod.

45-24-43. Sta: of proceedings on appeal to zoning board of review. - An appeal sball stay all proceedings in furcherance of the action appealed frod, unless the zoning enforcement offics or agenc: frow whon the appeal is taken certifies to the board of review, after an appeal shall heve baen duly filed, that by reason of facts state in the certificate a stay would in the officer's or agency's opinion cause imaineat peril to life or property. In sucb case proceedings shall not be stayed other than by a restrainiog order which may be granted by a court of competent jurisdiction on application tbereof and upon notice to the officer of agency from whom the appeal is taken on due cause shown. 

of review shall fix. reasonable time for the bearing ot sac appeal,

3 give public ootice thereof, as well as due notice to the parties in 4 interest, and decide the sane witbia teasonable time. Upon the hearing any party may appear in person or by ageot or by atcorney. its proceedr. 35 , showing the vote of each member upon each question, or if absent or fa:ling to vote, indicating sucb fact, and shall keep records of its examinations and other official actions, all of which shall be filed mmediately in the office of the board and shall be a public record. Copies of all records shall also be filed in the office of the zoning enforcement officer or agency.

45-24-46. Fediation option. - A zoning ordiance ary make provision for mediation of disagreements throught the procedures set forth in lhis section.

(a) Parties to proceedings authorized in sections 45-24-34, i5-24-39 through 45-24-45, 45-24-47 and 45-24-50 may utilize mediation as an ald in cimpleting such proceedings.

(b) In proceedings before the planning board or zoning board of review, in no case shall tae respective board initiate mediation or pirticipate as a rediatory party. Mediation shall supplement, not replace, those procedures in the above referenced section once they have been formally in:tated. Nothing in this section siall be aterpreted as expanding or limiting municipal police power or as modifying any praciples of substantive law.

(c) Participation : a mediation shall be wholly voluntary. The approprateness of mediation shall be determined by the particulars in each case and the willing:ess of the partias to negotiate.

(d) Any municipality oifering the mediation option shall assure that in eacb case, the diatang tres, assisted by the mediator as appropriate, develop terms and co: . ions for:

(1) Funding mediation. 
(2) Selectlas a oedietor tho, at siaim, hall have a working

knowledge of sunicipal zoning and subdivision procedures and dewastrated skills in eediation.

(3) Completing mediation, including time liaits for such completion.

(4) Suspending time limits otherwise authorized in inis chapter provided there is written consent by the medrating parties, and by an applicant or municipal decision-making body if either is not a party to the mediation.

(5) Identifying any additional important parties and affordiog thea the opporturity to participate.

(6) Subject to legal restrants, determining whetber some or all of the mediation sessions shall be open or closed to the public.

(7) Assurics that mediaced solutions are in writing and signed by the parties, and become subject of review and approval by the appropriate decision-making body pursuant to the authorized procedures set forth in the otber sections o: this chapter.

(e) No offers or statements made in the mediation sessions, excluding the final written mediated agreement, sball be admissible as evideace in any subsequent judicial or adoinistrative proceedings.

45-24-47. Appeals to superior court. - Any person or persoas josncly or severally agrieved by a decision of the zoning board may appeal to the superior court for the county in which the municipajity is situated by filing a complaint setting forth the reasoas of a apen withia tweaty (20) days after sucb decision bas beed flled ia tae office of the zoning board. The zoniag board shall file the origlaal documents acted upon by it and constituting the record of the case appealed from, or certified copies thereof, together with such other facts as may be pertigent, witb the clerk of the court witbin ten (10) days after being served with a copy of the complaint. When the complaint is filed by somecne other than che original applicant or appellust, such original applicant or appellant and the members of the 
zoning board shall be made, arties to such proceedings. The appeal

2 shall not stay proceedings upon tre decision appealed fron, but the court may, in its discretion, grant a stay on appropriate cerms and make such other orders as it deems necessary for an equitable disposition of the appeal.

If, before the date set for hearing in the superior court, application is made to the court for leave to present additional evidence before the zoning board and it is sbown to the satisfaction of the court that the additional evidence is material and that there were good reasons for the failure to present it at the hearing before the zoning board, tae court may order that the additional evidence be taken before the zonang board upon conditions determined by the court. The zoning board may modify its findings and decision by reason of sulh additionsl evidence and shall file that evidence and any modificotions, new indings or decisions with the superior coure.

The review shall be conducted by the superior court without a jury. The court shall consider the record of the hearing before the zoning board and if it shall appear to the court that additional evidence is necessary for the proper disposition of the natter, it way allow any farty to such appeal to present such evidence in open court, which evidence along with said repott shall constitute the record upon which the determination of tbe court shall be made.

ilie ivure jhall not substitute its judgant for that of the ,zoning board as to the weight of the evidence on questions of fact. The court may affird the decision of the zoning board or remand the case for further proceedings, or may reverse or modify the decision if substantial rights of the appellant have been prejudiced because of findings, anferences, conclusions or decisions which are: (1) in violation of consticutional, statutory or ordinance provisions: (2) in excess of the author:ty granted to the zoning board by statute or ordinance; (3) nale upon unlawful procedure; (4) 3 ffected by other error of law; 151 clearly erroneous in view of the reliablu. probative 
and substantial eviden:e of the whole record; or (6) arbicrary or capricious or chararierized by buse of discrecion or clearly unuar. ranted exercise of discretion.

The provisions of this section shall apply to appeals froa all zoning boards of review of any city or cown, whether or not such caty or town has adopted the provisions of this chapter.

45-24-48. Priority in judicial proceedings. - Upon the entry of any case or proceeding brought under the provisions of this chapter,

9 including pending appeals and appeals hereinafter taken . sa y court, referred to in section $45-24-47$, the court shall at toe rogest of either party advance the case, so that the matter shall be afforded

(a) To restrain the erection, alteration, or use of any building, structure, sign, or land erected, altered, or used in violation of the provisions of any zoning ordinance enacted under the autbority of this chapter, and to order its removal or abatement as a nuisance;

(b) To compel compliagce with the provisions of any zoning ordiance enacted under the authority of this chapter; and/or; 
.

(c) To order the resoval by the owner of any building, structure, siga or improvewent existing is rolation of any zoning ordinaoce enacted under the provisions of this chapter and to authorize soase official of such city or town ia default. such removal, the ouner to remove it at the expense of such owner.

45-24-51. Reimbursement to city or town. -. when wader the provisions of any judgment, order, or decree, in any such proceeding, any work as done or materials furaushed by an official of the city or Lown or by the order of such official, at the expense of the owner, in removing a building, structure, sign or other improvement unlawfully existing. the value of such work and material may be recovered in an action of the case, brought in said superior court against such owner, and if any such work or materials shall have been done or furnished by or at the cost of the city or town, such official shall cause the sare to be trnught in the name of the city or town.

45-24-52. Creat a of vested rights or encumbrances. -- Noching in this chapter or any ordinance enacted under the authority of this chapter shall create or be construed to create any -.ed gights in any person, firm, or corporation, or to be or create ang encu rances upon the title of any person, firm, or corporation in any property affected by any sucb ordinance.

45-24-53. Severability. -. If any provision of this chapter or of any rule, regulation or determiation made thereinder, or the application thereof to any person, agency or circumstances, is held invalad by $a$ court of competent jurisjaction, the rema:nder $\therefore$ : the chapter, rule, reguidtion, or determination and the app. cation of such provisions to other persons, agencies, or circunstances shail not be affected thereby. The invalidity of any section or sections or parts of any section or sections of this chapter shall not aftect the vaility of the remainder of the crapter.

SECTION 2. Chapter 1-3 of the General Laws entalled "Airport Zonang" is hereby amended as follows: 
2 severally assieved by any decision of the board of appeals, or any taxpayer, or any officer, de artment, board, or bureau of the political subdivision, or the airports division, ay appeal to the superior coure in the manner prescribed by 45-26-20 45-24-47 and the provisions of said section shall in all respects be applicable to said appeal.

SECTION 3. This act shall take effect upon passage.

a $=$ อ

ES741

- $\pm=0$ 
APPENDIX II 
Seccion 10 - Multi-Family Dwellings

1. Amend $E$.

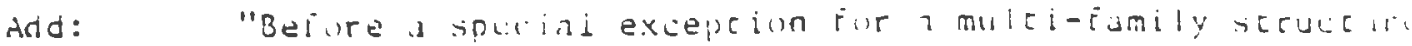
ur nulei-iamily Jevelupmene shall be tranced, lhe sich

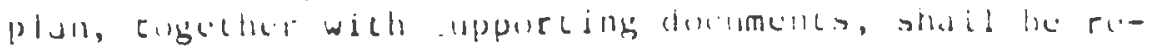
viewed by the Fusce: Plunning Ruard, weer which revic.... che Planning buard shall publisi a repore of ics índinis and recomendations pertalning to the coniormity uf che proposed development with she overall community plan, ocher Town pollcles including che encouragement of siliar energy and che cequtremencs of chis Section..."

2. Amend li - Sice PlaniBuilding Design

Inserc After n: "Conditions of the erace which can cast shad.ws incerfering with proposed or pocencial use of soiar energy syscems including exiscing and proposed iruccures, vegecdicion and major topographic suctires in che sitr.

3. Amend H - Standards For Development

Add 8. "Solar Review"

"The Plunning Board may require chat che developer demonscrace chat he has considercd using glte desigul techniques which preserve the pocencial for sular encriy. use and protect solar access in the develooment. Suct. cechniques may include buc need not be limited co: 1) scro... luc and builuing oriencacion wnich provides maximum snuchern exposure; 2) landscape planning which preserves sula access; 3) pacterns of developmenc which cake advancage of silope and ocher copngrahic reacures."

Sec! in!l I] - Seniur Ciepzen Group Huusing

1. Amend A - Purpose

"...to promote the use of land to Eacilicace a more economic and energy ef Eicient arrangement of buildinji, common sacilicies, vehicular circulacion and ucilicies..." 
Ti)W ()E FOSTER

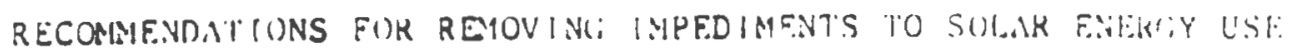

A. REMUYINC ZONINC BARRIERS

Arcicle I - Adminiscraciun and Procedure

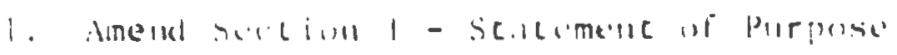

Add arcer: "... co provide adequare lighe and air... gu enculrage chu use of rencwable energy resourcus and primuco thergy eificienc pacterns of land use and developmenc."

Article II - District Use Regulacions

1. Aud Noce to 12 - Accessoyr Uses_

"Any use custumarily incident co uses permilced in the discrict and located on the sume lot.

*Noce - "sckached and decached sular enerzy syscellis including solar col lectors, scorage Escilisists and greenhouscs sha 11 be considered a Dermis: accessory use in all jiscricis."

Article IV - Special Regulations

1. Amond Sertion 2 - Yard Exi:upelons

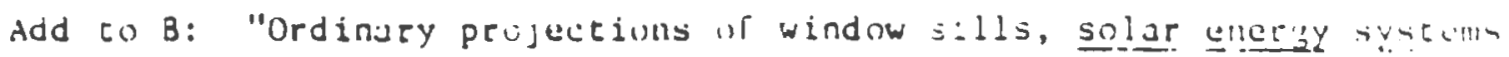
nr apparatus needed tu "perace. such syscems, vorulici ur other orname cal features may excend up co live ieer inc. the yard."

Add E: "Actached and decuched solar energy syseams includin!: solar collecturs, scorage [ailities and grueninuuses may be lucured in the side ur rear ird provided chey are placed 10 feet fiom che lor line. Such systcms inuy be erected in che front yard by specidi excenciun."

2. Hod Sectiun 12 - Height Exceptions:

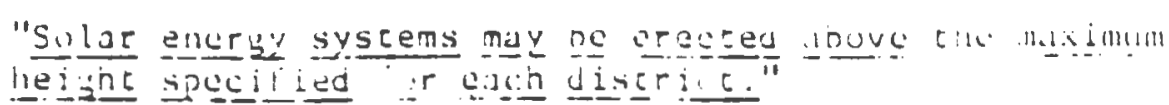


APPENDIX III 
TOWN ENERGY RESOLUTION

The Town Council of - resolve to promote the use of solar energy in the Town by encouraging energy efficient patterns of land use and development.

The Council finds that the use of renewable resources, in particular solar energy, will benefit the community by reducing con ity-wide dependence on expensive and unreliable fossil fuel supply. The $T A$ finds that renewable energy resources promise to offer a future energy source for the community which the Town ran preserve and protect through the following measures.

It is hereby resolved:

1) That the Town building inspector's office will make available information and advice concerning the opportunity for solar or energy efficient buliding ciesign and siting to individual or other applicants for building per its. This advise may include refertal to the Governor's Energy Oifice and Town boards or officials for additional incormation.

2) That the Town planning board will develop short and long term plans for promoting energy efficient suhdivision in the Town. The planning board shall consider and prepare amendments to the comprehensive plan, subdivision regulations and oning ordinance. These considerations should include, but not be iimited to educational eftorts for developers incorsuration of solar access provisions into subdivision review and proposals for modifications in the zoning ordinance to remove barriers to solar energy use. 
APPENDIX IV 
Table of contents

$\underline{\text { Page }}$

Introduction $\ldots \ldots \ldots \ldots \ldots \ldots \ldots \ldots \ldots \ldots \ldots \ldots \ldots \ldots \ldots \ldots \ldots \ldots \ldots \ldots \ldots$

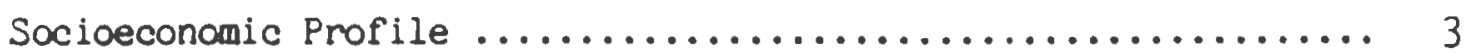

Energy Profile $\ldots \ldots \ldots \ldots \ldots \ldots \ldots \ldots \ldots \ldots \ldots \ldots \ldots \ldots \ldots \ldots \ldots \ldots$

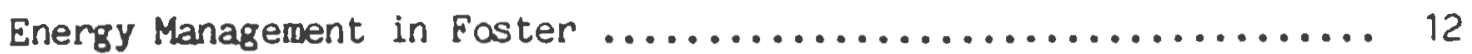

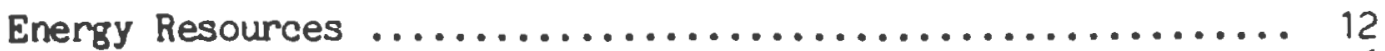

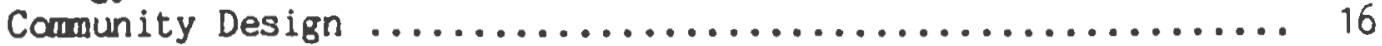

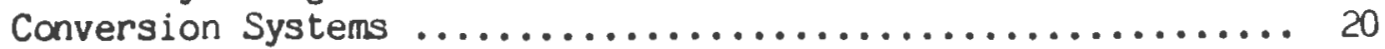

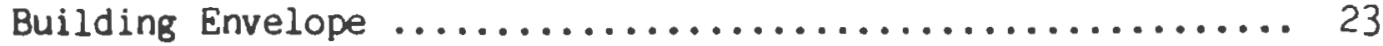

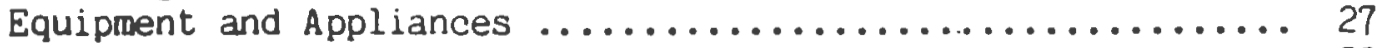

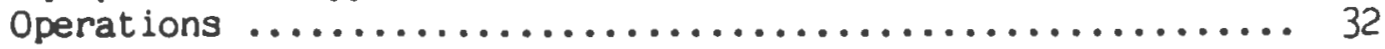

Sumary of Strategies and Policies Pertaining to Foster ....... 37

Future Energy Management $\ldots \ldots \ldots \ldots \ldots \ldots \ldots \ldots \ldots \ldots \ldots \ldots \ldots$

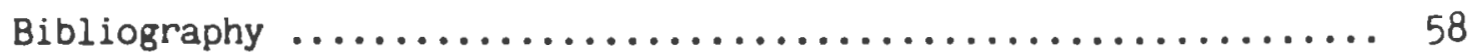


$\underline{\text { Page }}$

Table I - Analytic Components of the Comprehensive Energy

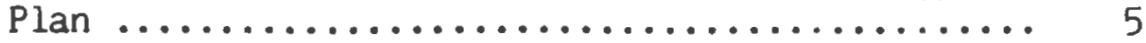

Table II - Foster Population by Age .................. 6

Table III - Number of Households in raster .............. 6

Table IV - Number of Persons per Dwelling Unit ........... 6

Table V - Total Year-Round Dwelling Units ............. 7

Table VI - Housing Types $\ldots \ldots \ldots \ldots \ldots \ldots \ldots \ldots \ldots \ldots \ldots \ldots$

Table VII - Number of Substandard Units ............... 7

Table VIII - Year Structure Built ................... 8

Table IX $\quad$ Median Income $\ldots \ldots \ldots \ldots \ldots \ldots \ldots \ldots \ldots \ldots \ldots . \ldots . \ldots$

Table $X \quad$ - Employment by Sector in Foster .............. 9

Table XI - Foster's Current Energy Status ............... 11

Table XII - Strategies for Energy Management in Energy Resources ......................... 17

Table XIII - Strategies for Energy Management in Community

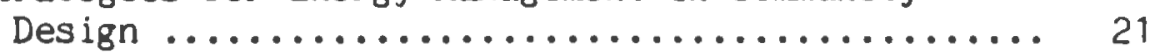

Table XIV - Strategies for Energy Management in Conversion

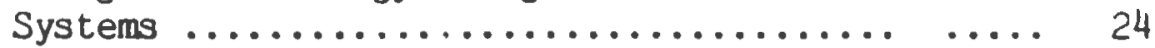

Table XV - Building Envəlope Energy Savings ............. 25

Table XVI - Retrofit Measures and Consumption Reductions ..... 28

Table XVII - Strategies for Energy Management in Building Envelope ............................ 29

Tabie XVIII - Energy Use and Cost of Equipment and Appliances ... 30

Table XIX - Strategies for Energy Management in Appliances

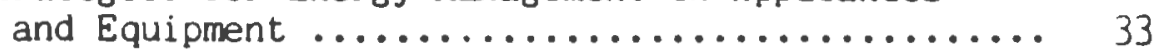

Table XX - Strategies for Energy Management in Operations .... 36

Table XXI - Foster Heating Costs .................... 41

Table XXII - Motor Vehicle Classification .............. 43 
APPENDIX V 
36 IT ORDaIlied by the inycr and Councll of the Town of Tass, that,

:Hapsas, It appering to the fown there exists a ereat dral of activity In the area of Sular Energy within the Town of Thos; and,

MiñRAS, Solar methods seem to be a viable and worthwhile source of encr collection; and,

TIEREAS, It has become necessary to protect the rights of those persons destring to use solar ther collection systen.

BE IT THETEFORE ORDAINED by the council of the Town of Taos as fol 's:

1. When a solar eneray collection system is installed on a jot, no siluctures or vegetation on an abutting lot shall be iucated so as to bilock the sulur collector's access to solar enerey. The protion or a solar collector that is protected is that portion winich:

a. Is located so as not to be shodcil kethicen the hours of 10:c0 A.M., and 3:00 P.K., by a hypothetlcel elght-foot obstruction loceted on the lot 11ne; and,

b. has an area not greater than one-halr of the beited rloor arca of the structure.

2: This subsection does not apply to structures or vegctation existing in an abutting lot at the time of installation of the solar enerey collcction system, or on the effective date of this ordiennce, whichever is later. This subsection controls any structure erected on, or vegetation planted in, abuttiug lots after the instrilation of the solar eneres collection system.

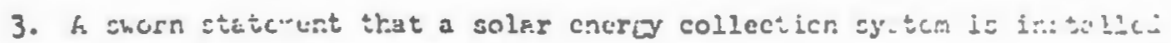
1r. the lot shell be riled with the Town Clerk, and the ciate of intailetion shall be the date of filing; if a sworn statenent is not riled, tiat sy-jur is not entitled to protection under this Crdinance.

- PASSED AND ADCPTED by the Counctl of the Town of Tros, on this day of 1978.
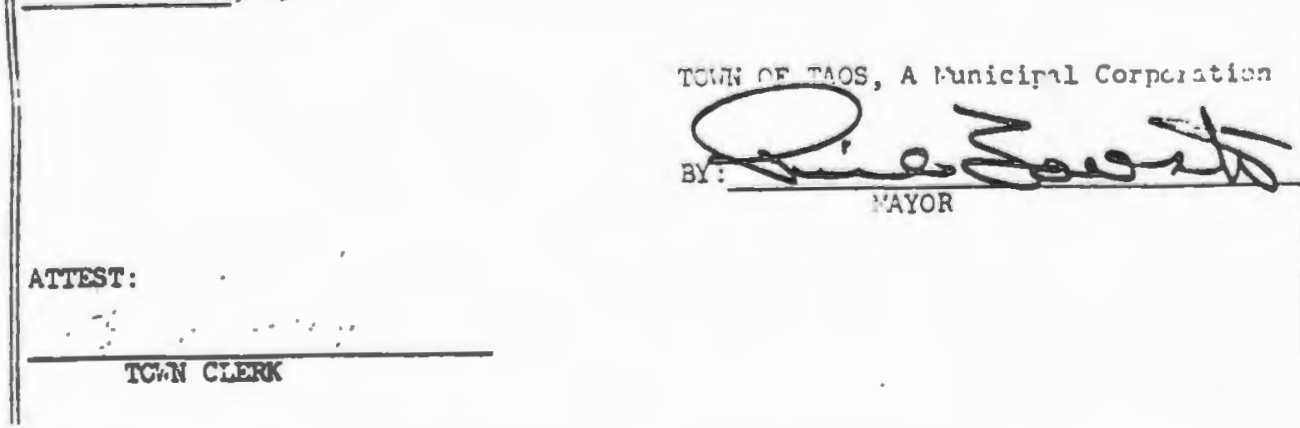
B IBL IOGRAPAY 
The American Planning Association. Promoting Solar Access for Residential Development: i Guidebook for Planning officialse Washington, DC: U.S. Government Printing Office. 1979.

Brooklyn har Rerley, "Solar Energy," Vol.45 1979, p. 354.

Connecticut Office of Policy and Management-Energy Division. Passive Solar Subdivision Design: A Planners Guidebook, November 1982 .

Collins, Cynthia, and Heise, Lori. Community Land Use Tools for Encouraging the Use of Solar Energy: A Tool Kit for Nine Rural Towns. Providence: R.I. League of Cities and Towns, 1982 .

Danielson, Luke J. "Drafting a Solar Access Ordinance: One City's Experience", Selar Law Reporter, March/April 1982, Vol.3 No. 6 Appendix.

Early, Duncan. "Energy Efficient Land Use", American Rlanning Association Journal, May 1979.

Eisenstadt, Melvin M. "Access to Solar Energy: The Problem and its' Current Status," Natural Resources Journale January 1982, Vol. 22 p. 40.

- "A Proposed Solar zoning Ordinance," Drban. Law Annuale $1978 \mathrm{Vol} .15$ p. 211.

日ayes, Gail Boyer. Solar Access Law: Protecting Access to Sunlight for Solar Energy Systems, Washington, DC Environmental Law Institute, May 1979.

"Out of the Shadows: Solar Access Law," Environmente Vol. 21 No. 7 pp 15-17; 19-20, September 1979.

Jaffee, Martin, "Some Comments on Drafting Solar Access Regulations," Land Use and Zoning Digest 30 (1978): 4-7.

Knowles, Ralph L., "The Solar Envelope," Solar Law Reporter, July/August 1980, Vol. 2 No. 2 pp 261-269.

Lawrence, William B., and Minan, John B. Legal Aspects of Solar Energy. Lexington: Lexington Books, 1981.

Maine Law Reyiew, "Nuisance and Solar Access," Vol. 32 1980, p. 439.

New England Law Review, "Legis'ative Approach to Solar Access: Transferable Development Rights", Vol. 13:4, 1978, p.847.

Pollock, Peter. Implementation of State Solar Incentives: Land Use Planning to Ensure Solar Access. Golden, CO: Solar Energy Research Institute, March 1979. 
Rhode Island League of Cities and Towns. Energy Planning and Managemente 1980.

Solar hav Reportere "Siting f Prutection", May/June 1980, Vol. 2 No. 1 pp 31-55.

Onited States Department of Energy. Local Government Energy Activities: Detailed Analysis of Trelve cities and counties. July 1979, Vol. 2.

Iniversity of colorade hav Revieve "The Allocation of Sunlight: Solar Rights and the Prior Appropriations Doctrine", Vol. 47 1976 , p. 431.

Urban Law Annuale "Solar Access Rights", 1982, Vol. 23 p. 437.

Mashburn Law Journal, "Solar Energy: An Analysis of the Implementation of Solar Zoning", 1979, Vol 17. p. 149.

Williams, Stephen F., Connecticut Law Reyiewe "Solar Access and Property Rights: A Maverick Analysis", Vol 111979 p. 430. 